\title{
Unexpected long-range transport of glyoxal and formaldehyde observed from the Copernicus Sentinel-5 Precursor satellite during the 2018 Canadian wildfires
}

\author{
Leonardo M. A. Alvarado ${ }^{1}$, Andreas Richter ${ }^{1}$, Mihalis Vrekoussis ${ }^{1,2,4}$, Andreas Hilboll ${ }^{1}$, \\ Anna B. Kalisz Hedegaard ${ }^{3,1}$, Oliver Schneising ${ }^{1}$, and John P. Burrows ${ }^{1}$ \\ ${ }^{1}$ Institute of Environmental Physics (IUP), University of Bremen, Bremen, Germany \\ ${ }^{2}$ Center of Marine Environmental Sciences (MARUM), University of Bremen, Bremen, Germany \\ ${ }^{3}$ Institute of Atmospheric Physics, German Aerospace Center (DLR), Oberpfaffenhofen-Wessling, Germany \\ ${ }^{4}$ Energy, Environment and Water Research Center, The Cyprus Institute, Nicosia, Cyprus
}

Correspondence: Leonardo M. A. Alvarado (lalvarado@iup.physik.uni-bremen.de)

Received: 29 July 2019 - Discussion started: 29 August 2019

Revised: 14 December 2019 - Accepted: 21 January 2020 - Published: 25 February 2020

\begin{abstract}
Glyoxal (CHOCHO) and formaldehyde (HCHO) are intermediate products in the tropospheric oxidation of the majority of volatile organic compounds (VOCs). CHO$\mathrm{CHO}$ is also a precursor of secondary organic aerosol (SOA) in the atmosphere. $\mathrm{CHOCHO}$ and $\mathrm{HCHO}$ are released from biogenic, anthropogenic, and pyrogenic sources. $\mathrm{CHOCHO}$ and $\mathrm{HCHO}$ tropospheric lifetimes are typically considered to be short during the daytime at mid-latitudes (e.g. several hours), as they are rapidly removed from the atmosphere by their photolysis, oxidation by $\mathrm{OH}$, and uptake on particles or deposition. At night and at high latitudes, tropospheric lifetimes increase to many hours or even days. Previous studies demonstrated that $\mathrm{CHOCHO}$ and $\mathrm{HCHO}$ vertical column densities (VCDs) are well retrieved from space-borne observations using differential optical absorption spectroscopy (DOAS). In this study, we present $\mathrm{CHOCHO}$ and $\mathrm{HCHO}$ VCDs retrieved from measurements by TROPOMI (TROPOspheric Monitoring Instrument), launched on the Sentinel5 Precursor (S5P) platform in October 2017. We observe strongly elevated amounts of $\mathrm{CHOCHO}$ and $\mathrm{HCHO}$ during the 2018 fire season in British Columbia, Canada, where a large number of fires occurred in August. $\mathrm{CHOCHO}$ and $\mathrm{HCHO}$ plumes from individual fire hot spots are observed in air masses travelling over distances of up to $1500 \mathrm{~km}$, i.e. much longer than expected for the relatively short tropospheric lifetime expected for $\mathrm{CHOCHO}$ and $\mathrm{HCHO}$. Comparison with simulations by the particle dispersion model FLEXPART (FLEXible PARTicle dispersion model) indi-
\end{abstract}

cates that effective lifetimes of $20 \mathrm{~h}$ and more are needed to explain the observations of $\mathrm{CHOCHO}$ and $\mathrm{HCHO}$ if they decay in an effective first-order process. FLEXPART used in the study calculates accurately the transport. In addition an exponential decay, in our case assumed to be photochemical, of a species along the trajectory is added. We have used this simple approach to test our assumption that $\mathrm{CHOCHO}$ and $\mathrm{HCHO}$ are created in the fires and then decay at a constant rate in the plume as it is transported. This is clearly not the case and we infer that $\mathrm{CHOCHO}$ and $\mathrm{HCHO}$ are either efficiently recycled during transport or continuously formed from the oxidation of longer-lived precursors present in the plume, or possibly a mixture of both. We consider the best explanation of the observed $\mathrm{CHOCHO}$ and HCHO VCD in the plumes of the fire is that they are produced by oxidation of longer-lived precursors, which were also released by the fire and present in the plume.

\section{Introduction}

Formaldehyde (HCHO) is produced by the oxidation of both methane $\left(\mathrm{CH}_{4}\right)$ and other volatile organic compounds (VOCs). Glyoxal (CHOCHO) is the smallest alphadicarbonyl formed by the oxidation of many VOCs containing two or more carbon atoms. Although both $\mathrm{CHOCHO}$ and $\mathrm{HCHO}$, which are known as OVOCs (oxygenated volatile 
organic compounds) have similar rates of reaction with the hydroxyl radical $(\mathrm{OH})$ in the troposphere, the photolysis frequency of HCHO, which absorbs and is photolysed in the ultraviolet-A (UV-A), is significantly smaller than that of $\mathrm{CHOCHO}$, which absorbs in the blue. As a result, the atmospheric lifetime of $\mathrm{HCHO}$ is longer than that of CHOCHO (Atkinson, 2000). Both species are short-lived during daytime due to their rapid removal by photolysis and reaction with $\mathrm{OH}$ radicals (Atkinson, 2000; Volkamer et al., 2007). These processes are the major sinks of $\mathrm{CHOCHO}$ and HCHO, contributing about $69 \%$ and $96 \%$, respectively. The remaining part of $\mathrm{HCHO}$ is removed by deposition (4\%), while for $\mathrm{CHOCHO} 22 \%$ is removed by secondary organic aerosol (SOA) formation and $8 \%$ by deposition (Stavrakou et al., 2009a, b). Additionally, HCHO and probably also CHO$\mathrm{CHO}$ during the night are removed by reaction with nitrate $\left(\mathrm{NO}_{3}\right.$ ) radicals (Atkinson, 2000). $\mathrm{CHOCHO}$ and $\mathrm{HCHO}$ play a key role in tropospheric chemistry because they act as temporary reservoirs releasing carbon monoxide $(\mathrm{CO})$ and $\mathrm{HO}_{x}$ $\left(\mathrm{OH}\right.$ and hydroperoxyl, $\mathrm{HO}_{2}$ ) free radicals, which participate in catalytic cycles creating and destroying tropospheric ozone $\left(\mathrm{O}_{3}\right)$.

The slant and vertical column densities of $\mathrm{HCHO}$ were first observed from space using measurements from the GOME instrument (e.g. Burrows et al., 1999, and references therein). These columns were later used to estimate the emission strength of precursor VOCs (Palmer et al., 2003; Abbot et al., 2003). The simultaneous observation of CHOCHO and HCHO (Wittrock et al., 2006) enabled an improved assessment of atmospheric VOC levels, and the knowledge of the ratio of $\mathrm{CHOCHO}$ to $\mathrm{HCHO}\left(R_{\mathrm{GF}}\right)$ (Vrekoussis et al., 2010) provides some differentiation of source types. Studies have used $\mathrm{HCHO}$, partly in combination with $\mathrm{CHOCHO}$ to estimate the biogenic isoprene emissions (Fu et al., 2007; Stavrakou et al., 2009a, b, c; Liu et al., 2012; Marais et al., 2012). This is the largest natural source of CHOCHO (Guenther et al., 2006; Fu et al., 2007). The amount of biogenically emitted VOCs depends on several factors including, amongst others, the plant species and weather conditions (e.g. temperature and humidity) (Guenther et al., 2000). In urban and rural regions, there are also contributions to the amounts of CHOCHO from human activities, such as from fossil fuel production, distribution, and combustion: the largest anthropogenic source of VOC precursors of CHOCHO being motor vehicle emissions due to either evaporation or incomplete combustion of fuel (Kansal, 2009). Globally, $55 \%$ of CHO$\mathrm{CHO}$ is produced by biogenic precursors, $27 \%$ is from anthropogenic emissions, and the remaining $18 \%$ is from pyrogenic emissions (Stavrakou et al., 2009b). Fires and vehicle exhausts are thought to be the only two sources which directly emit CHOCHO (Stavrakou et al., 2009b; Zhang et al., 2016).

In August 2018, unusually high temperatures caused severe drought in some areas of North America and resulted in the outbreak of many wildfires: the province of British
Columbia (BC) in Canada was one of the most affected areas. The 2018 season is the worst on record, with 6826 fires being detected and an area of approximately $22500 \mathrm{~km}^{2}$ of land burned (Natural Resources Canada, 2018). These fires emitted many different pollutants into the atmosphere, e.g. $\mathrm{CO}$, $\mathrm{NO}_{x}$, VOC, OVOC, $\mathrm{O}_{3}, \mathrm{SO}_{2}, \mathrm{CO}_{2}, \mathrm{HONO}, \mathrm{CH}_{3} \mathrm{COO}_{2} \mathrm{NO}_{2}$ (PAN), and other toxic species, as well as aerosols (Urbanski et al., 2018). During the transport of plumes from fires, photochemical transformation of emitted species occurs. Overall, polluted air is transported to regions where the plumes are dispersed. $\mathrm{CHOCHO}$ and $\mathrm{HCHO}$ column amounts are observed by remote sensing from satellite using differential optical absorption spectroscopy (DOAS) on measurements of the radiances backscattered from the Earth's surface and atmosphere. The global maps of $\mathrm{CHOCHO}$ and $\mathrm{HCHO}$ retrieved from SCIAMACHY, GOME-2, and OMI show enhanced $\mathrm{CHOCHO}$ and $\mathrm{HCHO}$ over tropical rain forests but also over other regions with high isoprene emissions. In addition, hot spots of $\mathrm{CHOCHO}$ and $\mathrm{HCHO}$ from fire emissions can be detected over large wildfires (Wittrock et al., 2006; Vrekoussis et al., 2009, 2010; Lerot et al., 2010; Chan Miller et al., 2014; Alvarado et al., 2014; De Smedt et al., 2008, 2012, 2015, 2018).

In this study, we present novel observations of $\mathrm{CHOCHO}$ and $\mathrm{HCHO}$ retrieved from the high spatial resolution observations by TROPOMI (TROPOspheric Monitoring Instrument) on board the Sentinel-5 Precursor (S5P) platform. On 7 August 2018, strongly elevated amounts of CHOCHO and $\mathrm{HCHO}$ were observed over British Columbia and attributed to being predominantly from fires. Surprisingly, these elevated levels of $\mathrm{CHOCHO}$ and $\mathrm{HCHO}$ were not limited to the vicinity of the fires. The fire plumes, which contain both $\mathrm{CHOCHO}$ and $\mathrm{HCHO}$, remained visible for several days and appeared to travel long distances from the sources. We have used forward simulations of atmospheric transport of air masses calculated using FLEXPART (FLEXible PARTicle dispersion model) (Pisso et al., 2019). The simulations include an effective first-order loss, which determines the mean effective lifetime of the tracer. Those tracers emitted over the fire hot spots with long effective lifetimes reproduce best the evolution of the plumes of $\mathrm{CHOCHO}$ and $\mathrm{HCHO}$ for most of the fire events, and thus provide estimates of the effective lifetimes of $\mathrm{CHOCHO}$ and $\mathrm{HCHO}$ in the plumes, as is described in the sections below. The $R_{\mathrm{GF}}$ provides knowledge about their sources in the plume. $\mathrm{CO}$ and nitrogen dioxide $\left(\mathrm{NO}_{2}\right)$ have respectively longer and shorter lifetimes with respect to reaction with $\mathrm{OH}$, and smoke and aerosol are also transported in the plumes from fires. Consequently, the retrieved vertical column densities of $\mathrm{CO}$ and $\mathrm{NO}_{2}$ from TROPOMI and true-colour images from the VIIRS (Visible Infrared Imaging Radiometer Suite) instrument on board NPP (Suomi National Polar-orbiting Partnership), which measures nearly simultaneously with TROPOMI, are used as complementary information in our interpretation of 
the apparent enhanced lifetime of $\mathrm{CHOCHO}$ and $\mathrm{HCHO}$ in the plume.

\section{Methods}

\subsection{CHOCHO and HCHO observations}

The differential optical absorption spectroscopy (DOAS) method has been successfully applied to retrieve atmospheric columns of trace gases having fingerprint narrow absorption bands in the solar spectral range from space-borne instruments (e.g. Burrows et al., 1999). As noted above, there are several studies describing retrievals of OVOCs and their use for the identification of VOC sources and their emissions (Burrows et al., 1999; Palmer et al., 2001; Wittrock et al., 2006; Kurosu et al., 2007; Vrekoussis et al., 2009, 2010; Lerot et al., 2010; De Smedt et al., 2008, 2012, 2015, 2018; Hewson et al., 2013; González Abad et al., 2015; Chan Miller et al., 2014; Alvarado et al., 2014, 2015). Algorithms for the retrieval of $\mathrm{HCHO}$ and $\mathrm{CHOCHO}$ have been developed for measurements from the SCanning Imaging Absorption spectroMeter for Atmospheric CHartographY (SCIAMACHY) (Burrows et al., 1995; Bovensmann et al., 1999), the Ozone Monitoring Instrument (OMI) (Levelt et al., 2006), and the second Global Ozone Monitoring Experiment on MetOp-A and -B (GOME2-A and -B) (Munro et al., 2016), which in combination provide a continuous dataset covering a period of more than 20 years. In this study, measurements from TROPOMI on board the Sentinel-5 Precursor (Veefkind et al., 2012) are used to retrieve atmospheric column amounts of $\mathrm{CHOCHO}$ and $\mathrm{HCHO}$. A brief instrument description and relevant details of the retrieval of $\mathrm{CHOCHO}$ and $\mathrm{HCHO}$ are given below.

\subsection{TROPOMI}

The TROPOspheric Monitoring Instrument (TROPOMI) on board the Copernicus Sentinal-5 Precursor satellite was launched on 13 October 2017. It has a spectral range in the UV-Vis-NIR-SWIR, covering wavelengths from 270 to $500 \mathrm{~nm}$ in the UV-Vis (ultraviolet to visible), from 675 to $775 \mathrm{~nm}$ in the NIR (near-infrared), and a band from 2305 to $2385 \mathrm{~nm}$ in the SWIR (shortwave infrared). These bands allow for the observation of several relevant atmospheric species, including $\mathrm{CHOCHO}, \mathrm{HCHO}, \mathrm{NO}_{2}$, and $\mathrm{CO}$. TROPOMI provides nearly global coverage each day at a spatial resolution which in August 2018 was $3.5 \mathrm{~km} \times 7 \mathrm{~km}$ $(7 \mathrm{~km} \times 7 \mathrm{~km}$ in the SWIR). The Equator crossing time is 13:30 LT (ascending node). Similar to OMI, TROPOMI is a nadir-viewing imaging spectrograph, employing a twodimensional CCD (charge-coupled device): one dimension collecting the spectral information and the other being used for the spatial information. TROPOMI on board the S5P satellite provides data since November 2017 (Veefkind et al., 2012).

\subsection{CHOCHO retrieval from TROPOMI measurements}

In recent years, several improvements in the retrieval of CHOCHO have been reported. In 2014, Chan Miller et al. (2014) and Alvarado et al. (2014) presented new CHO$\mathrm{CHO}$ retrieval algorithms applied to OMI measurements. These studies, similar to previous studies on GOME2-A data, introduced approaches to reduce interference by other absorbers, such as liquid water and $\mathrm{NO}_{2}$. In this study, an optimized retrieval algorithm for $\mathrm{CHOCHO}$ was developed, building on the heritage from the OMI CHOCHO retrieval presented by Alvarado et al. (2014) and extended and applied to S5P measurements. Previous studies have shown that cross-correlations between reference cross sections, as well as instrumental structures and shifts in the wavelength calibration, can introduce systematic errors in the retrieval. As a result, a strong dependence on the fitting window was identified in the retrieved $\mathrm{CHOCHO}$ slant column densities (SCDs) (Chan Miller et al., 2014; Alvarado et al., 2014). In this study, a fitting window from 433 to $465 \mathrm{~nm}$ was chosen, which is slightly larger than windows used in previous investigations (Vrekoussis et al., 2010; Alvarado et al., 2014). This fitting window, which enables the liquid water absorption to be retrieved, leads to a reduction in the number of negative $\mathrm{CHOCHO}$ SCDs over oceanic regions in comparison to a shorter fitting window (e.g. $434-458 \mathrm{~nm}$ ), as well as a reduction in the residuals. The wavelength range selected covers the strong absorption bands of CHOCHO (452$457 \mathrm{~nm}$ ), which have already been used in the past to retrieve CHOCHO from ground- and ship-based DOAS configurations as well as from satellites (Sinreich et al., 2007, 2010; Wittrock et al., 2006; Vrekoussis et al., 2009, 2010; Lerot et al., 2010; Chan Miller et al., 2014; Alvarado et al., 2014; Behrens et al., 2019). In order to optimize the quality of the retrievals, a row-dependent daily mean Pacific spectrum from the region $50^{\circ} \mathrm{S}, 160^{\circ} \mathrm{E}$ to $50^{\circ} \mathrm{N}, 135^{\circ} \mathrm{W}$ is used as a background spectrum (Alvarado, 2016), which is computed by averaging over the whole latitude range $\left(50^{\circ} \mathrm{S}\right.$ to $\left.50^{\circ} \mathrm{N}\right)$ for each across-track viewing direction independently. In addition, the mean $\mathrm{CHOCHO} \mathrm{SCD}$ over the region $30^{\circ} \mathrm{S}, 150^{\circ} \mathrm{W}$ to $30^{\circ} \mathrm{N}, 150^{\circ} \mathrm{E}$ is computed each day and subtracted from all SCDs to correct for possible offsets. A summary of the selected absorption cross sections, and other parameters used in the retrieval as well as a list of the species included in the retrieval, is shown in Table 1.

SCDs depend on observation geometry. Vertical column densities (VCDs) are derived from the SCDs by use of socalled air mass factors (AMFs), which depend on the tracegas profile, surface albedo, aerosols, clouds, and on solar zenith angle and measurement geometry. As the focus of this study is the observation of $\mathrm{CHOCHO}$ in biomass burning emissions, a simple $\mathrm{CHOCHO}$ profile with a Gaussian distribution having its maximum peak at the altitude of the aerosol layer is used (see Fig. 1a). This is based on the as- 
Table 1. Summary of retrieval parameters of $\mathrm{CHOCHO}$ and $\mathrm{HCHO}$ from S5P with the respective absorption cross sections used.

\begin{tabular}{lll}
\hline Parameters & Formaldehyde (HCHO) & Glyoxal (CHOCHO) \\
\hline $\begin{array}{l}\text { Fitting window } \\
\text { Polynomial }\end{array}$ & $323.5-361 \mathrm{~nm}$ & $433-465 \mathrm{~nm}$ \\
5 coefficients
\end{tabular}

(a) Gaussian profile: 10 Aug 2018

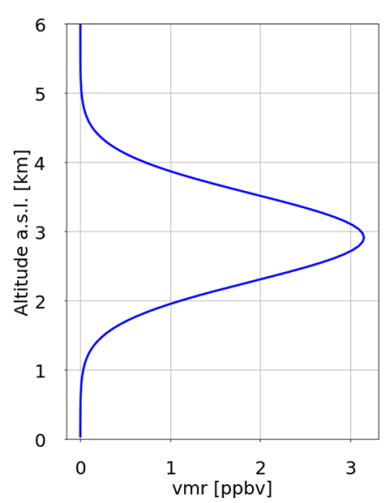

(b) Average aerosol profile: 10 Aug 2018 Lat.: $50^{\circ} \mathrm{N}-60^{\circ} \mathrm{N}$; Long.: $94^{\circ} \mathrm{W}-99^{\circ} \mathrm{W}$

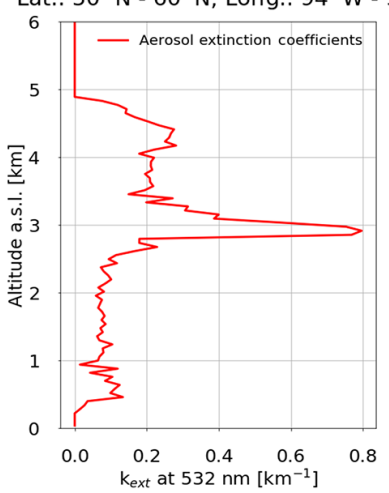

(c) CALIPSO aerosol profiles: 10 Aug 2018

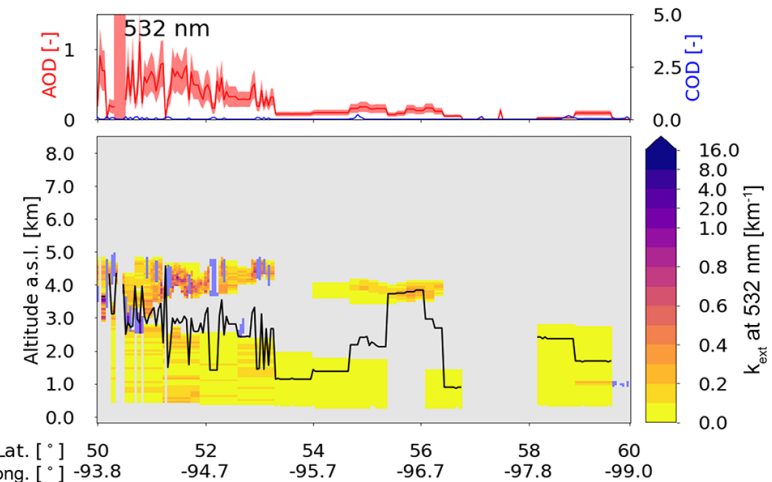

Figure 1. (a) $\mathrm{CHOCHO}$ and $\mathrm{HCHO}$ profiles assumed in the computation of AMFs (air mass factors). (b) CALIPSO profile of aerosol extinction coefficients $\left(k_{\text {ext }}\right)$, averaged over for all latitudes and longitudes of panel (c), excluding cloudy scenes. (c) Top panel: example of CALIPSO aerosol profile extinction coefficients retrieved at a wavelength of $532 \mathrm{~nm}$. Aerosol and cloud optical depths (AOD and COD, respectively) are shown as a function of latitude and longitude for every single profile. Bottom panel: colour-coded $k_{\text {ext }}$ for every latitude and longitude in the selected region. Purple spots represent cloudy scenes. The black line depicts the aerosol layer height.

sumption that $\mathrm{CHOCHO}$ is found at the same location as the main plume of aerosol and other trace gases. The altitude of the aerosol layer was estimated from profiles retrieved by the Cloud-Aerosol Lidar and Infrared Pathfinder Satellite Observation (CALIPSO) (Vaughan et al., 2004) (Fig. 1b). These aerosol extinction coefficient $\left(k_{\text {ext }}\right)$ profiles retrieved at $532 \mathrm{~nm}$ are also used in the calculation of the AMFs by the radiative transfer model SCIATRAN (Rozanov et al., 2013).
The computations have been performed on a daily basis, assuming a single scattering albedo of 0.92 and a homogenous distribution of aerosols characterized by the mean profile in the whole region of study. The latter is computed from the average of all aerosol profiles taken over the region after removing cloud-contaminated pixels (see Fig. 1c). Clouds are not explicitly accounted for in the $\mathrm{CHOCHO}$ and $\mathrm{HCHO}$ retrievals, but data are filtered for the presence of clouds using 
an intensity criterion corresponding to a cloud radiance fraction of about $50 \%$.

\subsection{HCHO retrieval from TROPOMI measurements}

The accuracy of DOAS retrievals of $\mathrm{HCHO}$ is limited by cross-correlations with strong absorbers in the UV (e.g. $\mathrm{O}_{3}$ ) and the signal-to-noise ratio of the radiance spectra measured by the instrument. Here, an updated and optimized version of the formaldehyde retrieval developed by Wittrock et al. (2006) and Vrekoussis et al. (2010) is used, which applies a slightly larger fitting window extending from 323.5 to $361 \mathrm{~nm}$, resulting in a reduction in the noise of the retrieved slant column densities. At wavelengths shorter than $336 \mathrm{~nm}$, interference with $\mathrm{O}_{3}$ is observed due to the small optical depth of $\mathrm{HCHO}$, which is about 3 orders of magnitude smaller. This effect is compensated by applying the method described by Pukīte et al. (2010), which consists of adding two additional pseudo cross sections to the fit $\left(\lambda \sigma_{\mathrm{O}_{3}}\right.$ and $\sigma_{\mathrm{O}_{3}}^{2}$ ) (Pukīte et al., 2010; De Smedt et al., 2008, 2015, 2018). The cross sections of interfering species are included in the fit as listed in Table 1 . In a manner similar to the retrieval of $\mathrm{CHOCHO}$, a synthetic ring spectrum (Vountas et al., 1998) is used to account for the ring effect and a row-dependent daily mean Pacific spectrum from the region $50^{\circ} \mathrm{S}, 135^{\circ} \mathrm{W}$ to $50^{\circ} \mathrm{N}, 16^{\circ} \mathrm{E}$ is used as background spectrum. A latitude-dependent offset correction based on SCDs from longitudes between $180^{\circ} \mathrm{E}$ and $160^{\circ} \mathrm{E}$ is applied to the data. As for CHOCHO, VCDs are computed using AMFs, assuming a Gaussian shape for the distribution of $\mathrm{HCHO}$ at the layer where the aerosols are located in the plume. Figure $2 \mathrm{a}$ and $\mathrm{b}$ show examples of $\mathrm{CHOCHO}$ and $\mathrm{HCHO}$ fit results for 10 August 2018 compared to the differential reference cross section for a single measurement. For an individual $\mathrm{CHOCHO}$ measurement, the detection limit is of the order of $5 \times 10^{14}$ molec. $\mathrm{cm}^{-2}$, which is about 10 times smaller than the columns detected from emissions of the wildfires over the British Columbia region of Canada. For $\mathrm{HCHO}$, the detection limit is an order of magnitude higher $\left(4.5 \times 10^{15}\right.$ molec. $\left.\mathrm{cm}^{-2}\right)$. The detection limit of a single S5P measurement in this study has been estimated in a manner similar to that explained in Alvarado et al. (2014).

\subsection{Simulation of tracer transport with FLEXPART}

In order to simulate the transport of emissions from the Canadian wildfires, forward simulations with version 10.3 of the FLEXible PARTicle dispersion model (FLEXPART) (Stohl et al., 2005; Pisso et al., 2019) have been performed. The model was driven by using hourly wind fields from the ECMWF (European Centre for Medium-Range Weather Forecasts) ERA5 reanalysis (C3S) at $0.25^{\circ}$ horizontal resolution. As a transport model, FLEXPART does not simulate the complete set of chemical transformations leading to the observed lifetimes of trace gases in the biomass burning

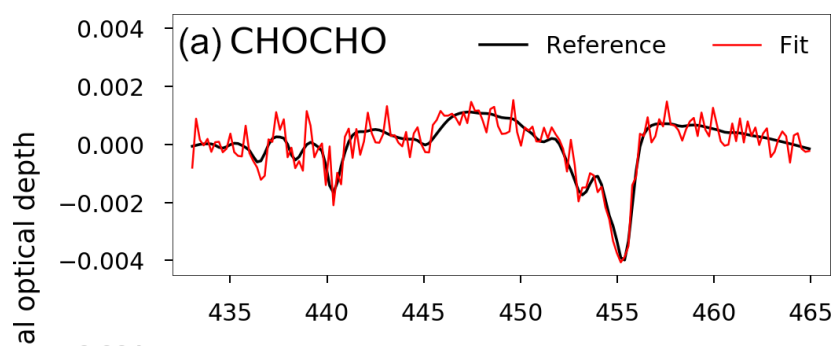

0.004 (b) $\mathrm{HCHO}$

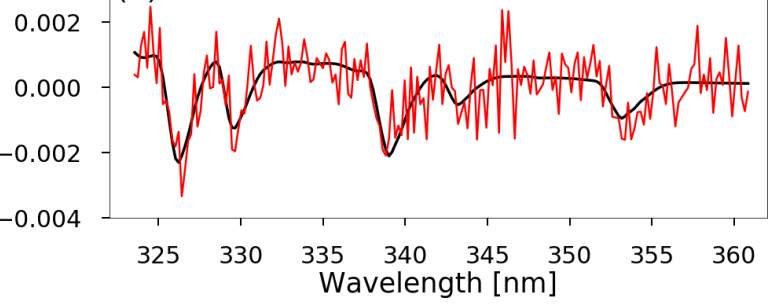

Figure 2. (a) Example fit for $\mathrm{CHOCHO}$ from a single measurement of S5P taken at latitude $53.0^{\circ}$ and longitude $125.6^{\circ} \mathrm{W}$ on $10 \mathrm{Au}$ gust 2018 and for a solar zenith angle of $39.3^{\circ}$. (b) Example fit for $\mathrm{HCHO}$ from a single measurement of S5P taken at latitude $59.1^{\circ}$ and longitude $109.0^{\circ} \mathrm{W}$ on 10 August 2018 and for a solar zenith angle of $44.6^{\circ}$. The black line depicts the scaled differential cross section and the red line the fit. The SCD values for this example are $9.3 \times 10^{15}$ molec. $\mathrm{cm}^{-2}$ for $\mathrm{CHOCHO}$ and $4.6 \times 10^{16}$ molec. $\mathrm{cm}^{-2}$ for $\mathrm{HCHO}$, respectively. The detection limit for a single measurement from S5P is estimated to be $5.0 \times 10^{14}$ molec. $\mathrm{cm}^{-2}$ and $4.5 \times 10^{15}$ molec. $\mathrm{cm}^{-2}$ for $\mathrm{CHOCHO}$ and $\mathrm{HCHO}$, respectively.

plumes. However, performing simulations for tracers having different mean lifetimes yields a valuable piece of information in order to understand the observed plume evolution. An effective mean lifetime can be estimated by comparing the observed behaviour of the $\mathrm{CHOCHO}$ and $\mathrm{HCHO}$ with FLEXPART simulations of different assumed tracer lifetimes.

In FLEXPART, the effective mean lifetime $\tau$ of an emitted tracer is treated as exponential decay with a given half-life $\left(t_{0.5}\right) ; \tau$ can then be calculated according to $\tau=t_{0.5} / \ln (2)$. As part of this study, FLEXPART simulations were carried out with half-life times of 2, 4, 6, 8, 10,12,14, 16, 18, and $20 \mathrm{~h}$, corresponding to effective mean lifetimes of $\sim 2.9,5.8$, $8.7,11.5,14.4,17.3,20.2,23.1,26.0$, and $28.9 \mathrm{~h}$, respectively. As emission rates from wildfires are highly uncertain, the emission fluxes from the Canadian wildfires are assumed to be proportional to fire radiative power (FRP; see below for more details). The emissions, prescribed in the model, are taken from the Global Fire Assimilation System (GFAS) daily FRP and plume height data (Rémy et al., 2017). Simulations were performed on a daily basis for the period 6 to 23 August 2018. For each day, all fires from the GFAS data, which had an FRP of more than $3 \mathrm{~W} \mathrm{~cm}^{-2}$, were gridded to a $0.350^{\circ}$ horizontal pattern. The model was then run forward in time for $120 \mathrm{~h}$, releasing the tracer for the first $24 \mathrm{~h}$ (the full 
(a) $\mathrm{CHOCHO}$ VCD: August 2018

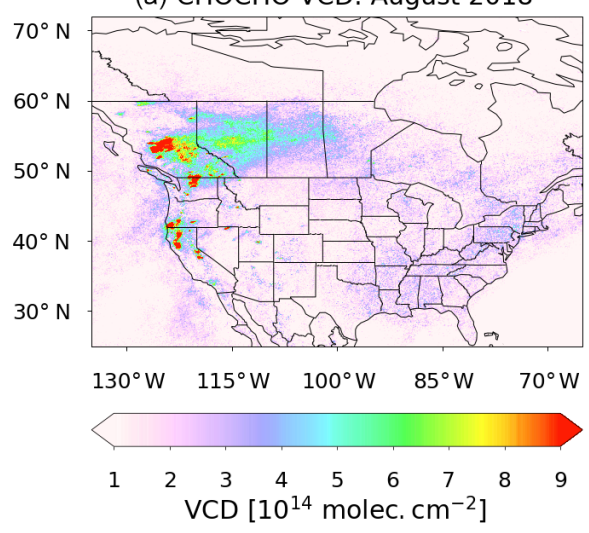

(b) HCHO VCD: August 2018

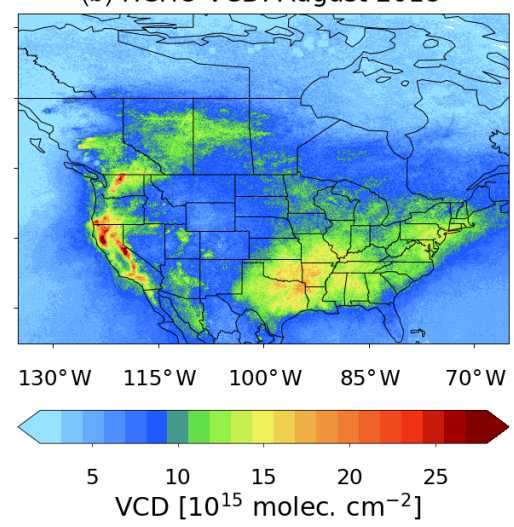

(c) Fire radiative power: August 2018

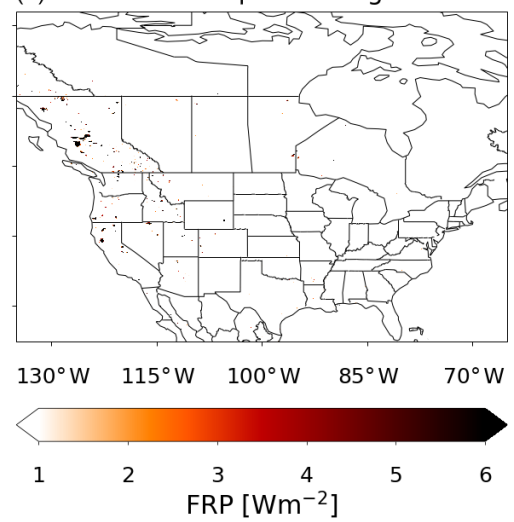

Figure 3. Monthly average of CHOCHO (a) and HCHO (b) VCDs retrieved from TROPOMI on S5P for August 2018 and over North America (a, b). Panel (c) shows the integrated FRP (fire radiative power) from MODIS for the same period.

UTC day) from each of the $0.350^{\circ}$ grid cells, assuming no temporal variation throughout the day. Vertically, the emissions within the grid cells were evenly distributed over the range of mean altitude of maximum injection heights given by the GFAS data for the respective grid cell. The output of the simulation contains gridded mass concentrations for each time step. Here, a grid with a horizontal resolution of $0.03125^{\circ}$ was chosen to match the resolution of the gridded satellite observations. Hourly output from the simulation was recorded and then vertically integrated to yield simulated tracer columns. In a post-processing step, for one specific mean lifetime, all simulation results (i.e. simulations for all fires on all days) were aggregated into one dataset. While the absolute tracer column density from the model output cannot be simply compared to the measurements, a comparison of the plume patterns and relative distribution between satellite observation and model output gives an indication about the meaningfulness of the prescribed mean lifetime. At this point, the aggregated model output for one effective mean lifetime consists of hourly latitude-longitude grids of vertical tracer columns throughout the whole study period. For comparison to the satellite observations, the hourly time slice closest to the time of overpass at $53^{\circ} \mathrm{N}$ was chosen.

\section{Results and discussion}

During August 2018, a high-temperature anomaly led to the outbreak of many fires in the Canadian western province of British Columbia, resulting in the emission of large quantities of particles and trace gases that in turn affected air quality in the region. As shown in Fig. 3a and b, the monthly average of CHOCHO and HCHO vertical columns from S5P show strongly enhanced values over the fire region, suggesting that these fires were a large, direct, and/or indirect source of $\mathrm{CHOCHO}$ and HCHO. Surprisingly, the CHOCHO and $\mathrm{HCHO}$ enhancements are not limited to the main fire re- gion but extend over large parts of Canada, where only a few fires were observed. In order to investigate the sources of $\mathrm{CHOCHO}$ and $\mathrm{HCHO}$ and their distributions, $24 \mathrm{~h}$ assimilation data of fire radiative power from the Global Fire Assimilation System (Kaiser et al., 2012) are analysed. Briefly, FRP is a measure of outgoing radiant heat from fires, measured in units of watt per square centimetre $\left(\mathrm{W} \mathrm{cm}^{-2}\right)$ and retrieved from space by the MODerate resolution Imaging Spectroradiometer (MODIS) on board of the Terra and Aqua satellites (Justice et al., 2002). The assimilated FRP spatially aggregates all valid fire and non-fire observations from both MODIS instruments onto a horizontal resolution of $0.1^{\circ} \times 0.1^{\circ}$ and computes the total FRP sums for each grid bin (Justice et al., 2002). The FRP is also used as input in the FLEXPART simulation as described in Sect. 2.5 as a proxy for emission strength. Figure $3 \mathrm{c}$ shows a monthly-average FRP map over North America for August 2018.

The highest CHOCHO VCD values are found over the locations of the most intense fires, as intuitively expected. The $\mathrm{HCHO}$ distribution over the fire regions is similar to that of $\mathrm{CHOCHO}$ but with some differences in the relative distribution. In addition, enhanced $\mathrm{CHOCHO}$ and $\mathrm{HCHO}$ columns are also apparent over the south-eastern US, where large isoprene emissions occur. $\mathrm{CHOCHO}$ and $\mathrm{HCHO}$ are also detected in plumes crossing central and eastern Canada, where no fires are identified in the FRP map. This pattern is best explained by the transport of $\mathrm{CHOCHO}$ and $\mathrm{HCHO}$ emanating from the wildfires. However, $\mathrm{CHOCHO}$ and $\mathrm{HCHO}$ have been reported to have short atmospheric lifetimes of about $\sim 2.2$ and $\sim 4.0 \mathrm{~h}$ during daytime, respectively (Atkinson, 2000; Volkamer et al., 2005a). Assuming that the lifetime in the plume is similar to that observed at the ground, we expect that $\mathrm{CHOCHO}$ would be removed reasonably close to the fire sources. HCHO would be transported further, but we also expect that it would be transported no more than approximately twice as far as $\mathrm{CHOCHO}$. 


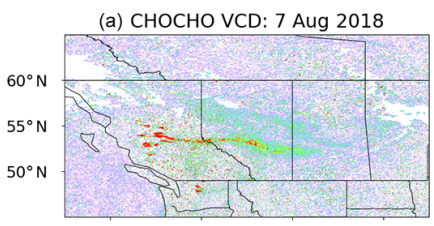

(b) HCHO VCD: 7 Aug 2018

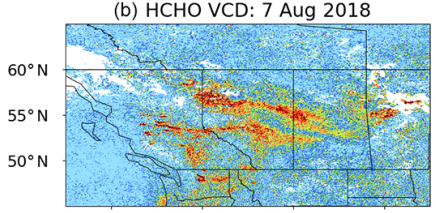

(c) FLEXPART: 7 Aug 2018

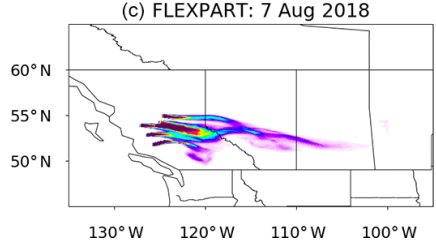

CHOCHO VCD: 8 Aug 2018

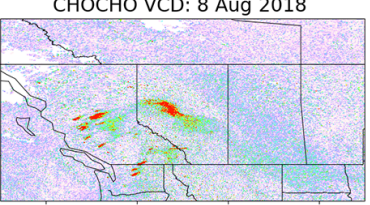

HCHO VCD: 8 Aug 2018

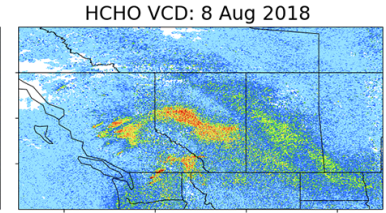

FLEXPART: 8 Aug 2018

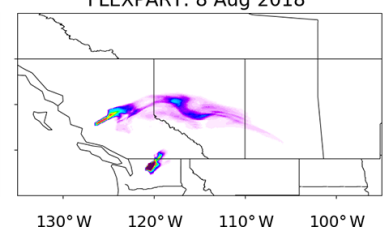

CHOCHO VCD: 9 Aug 2018

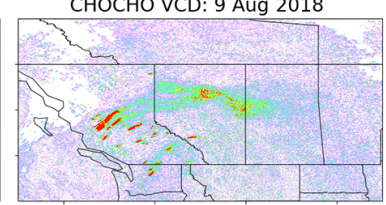

HCHO VCD: 9 Aug 2018

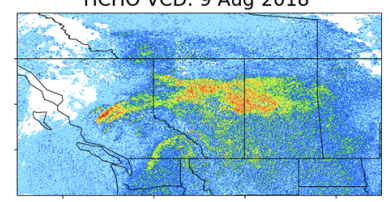

FLEXPART: 9 Aug 2018

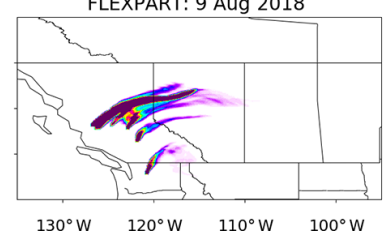

CHOCHO VCD: 10 Aug 2018

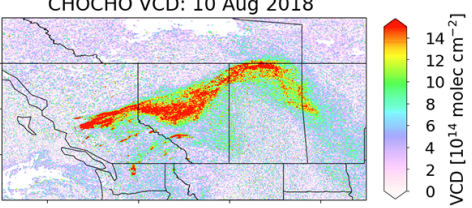

HCHO VCD: 10 Aug 2018

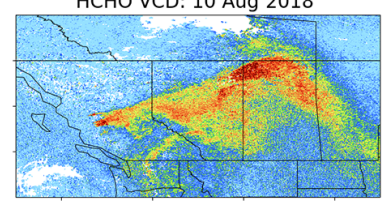

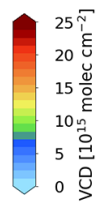

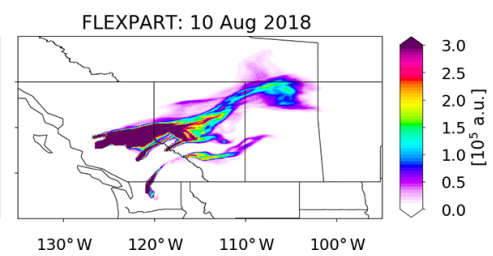

Figure 4. (a, b) Daily CHOCHO and HCHO VCDs retrieved from S5P measurements for the period 7 to 10 August 2018. (c) Distribution of a tracer with a lifetime of $14.4 \mathrm{~h}$ simulated with FLEXPART for the same period. The CHOCHO in the plume decreases on average from $3 \times 10^{15}$ to $3 \times 10^{14}$ molec. $\mathrm{cm}^{-2}$, while the HCHO has a different variation in the plume, but at the end of the plume it decreases from $3 \times 10^{16}$ to $1 \times 10^{16}$ molec. $\mathrm{cm}^{-2}$. The FLEXPART tracer column decreases from $3 \times 10^{6}$ to $0.3 \times 10^{6}$ for this specific effective lifetime of $14.4 \mathrm{~h}$.

Earlier studies by Wittrock et al. (2006) and Vrekoussis et al. $(2009,2010)$ showed that $\mathrm{CHOCHO}$ is also observed over oceanic regions, where no $\mathrm{CHOCHO}$ source is expected. The potential of (a) a long-range transport of $\mathrm{CHOCHO}$ and/or of CHOCHO precursors from continental areas and (b) having an unknown oceanic $\mathrm{CHOCHO}$ source were discussed as a possible explanation in part of these observations, but no firm conclusions could be drawn so far. In the present study, with the support of the simulations using FLEXPART, evidence of long-range transport of $\mathrm{CHOCHO}$ and $\mathrm{HCHO}$ or its precursors from biomass burning emissions is investigated. In this context, the transport of $\mathrm{CHOCHO}$ and $\mathrm{HCHO}$ during two fire plume episodes form different periods (7-10 and 20-21 August 2018) are discussed below.

\subsection{CHOCHO and HCHO emissions from the British Columbia wildfires: 7-10 and 20-21 August 2018}

Figure 4a shows daily maps of CHOCHO and HCHO VCDs over Canada for the period 7 to 10 August 2018. The most intense wildfires are found on 7 August 2018 and remain detectable until 10 August 2018. Both CHOCHO and HCHO plumes are detected on the first day of the fire. The CHO$\mathrm{CHO}$ and $\mathrm{HCHO}$ distributions then change from day to day. However, a large plume is clearly visible on 10 August 2018. Enhanced $\mathrm{CHOCHO}$ and $\mathrm{HCHO}$ columns are found at a distance of up to $\sim 1500 \mathrm{~km}$ from the fires, indicating transport over long distances.

To investigate possible transport pathways, forward simulations of the atmospheric transport with FLEXPART were calculated for the period when $\mathrm{CHOCHO}$ and $\mathrm{HCHO}$ plumes are observed (see Fig. 4b), assuming an effective lifetime of $14.4 \mathrm{~h}$. The latter is significantly longer than lifetimes of $\mathrm{CHOCHO}$ and $\mathrm{HCHO}$ found in the literature. On the other hand, the simulated pattern of air masses follows the same distinctive path as CHOCHO and HCHO VCDs. The tracer simulated with FLEXPART spreads over the same area as $\mathrm{CHOCHO}$, providing evidence for the transport of $\mathrm{CHOCHO}$ and $\mathrm{HCHO}$ and their precursors over continental Canada. This is more evident for the second period of interest in this study, which extends from 20 to 21 August 2018 (see Fig. 7). While the spatial match of plume and model is good in this example, it is clear from the figure that an effective lifetime of $14.4 \mathrm{~h}$ does not describe fully the extent of $\mathrm{CHOCHO}$ and $\mathrm{HCHO}$ transported. Using shorter effective lifetimes for $\mathrm{CHOCHO}$ and $\mathrm{HCHO}$, taken form the literature, would not reproduce the observations. However, both lifetimes depend on conditions in the plume: on the diurnal photolysis and $\mathrm{OH}$ diurnal cycles as well as on wet/dry deposition processes and other oxidants. Consequently, comparisons of FLEXPART simulations with different effective lifetimes were performed for 2 selected days, as is shown in Sect. 3.2.

\subsection{Effective lifetimes of $\mathrm{CHOCHO}$ and $\mathrm{HCHO}$ in the plume}

Figure 5 shows the results of FLEXPART simulations assuming effective lifetimes for a surrogate chemical species of $\sim 2.9,14.4,23.1$, and $28.9 \mathrm{~h}$ for 10 and 20 August 2018 . 


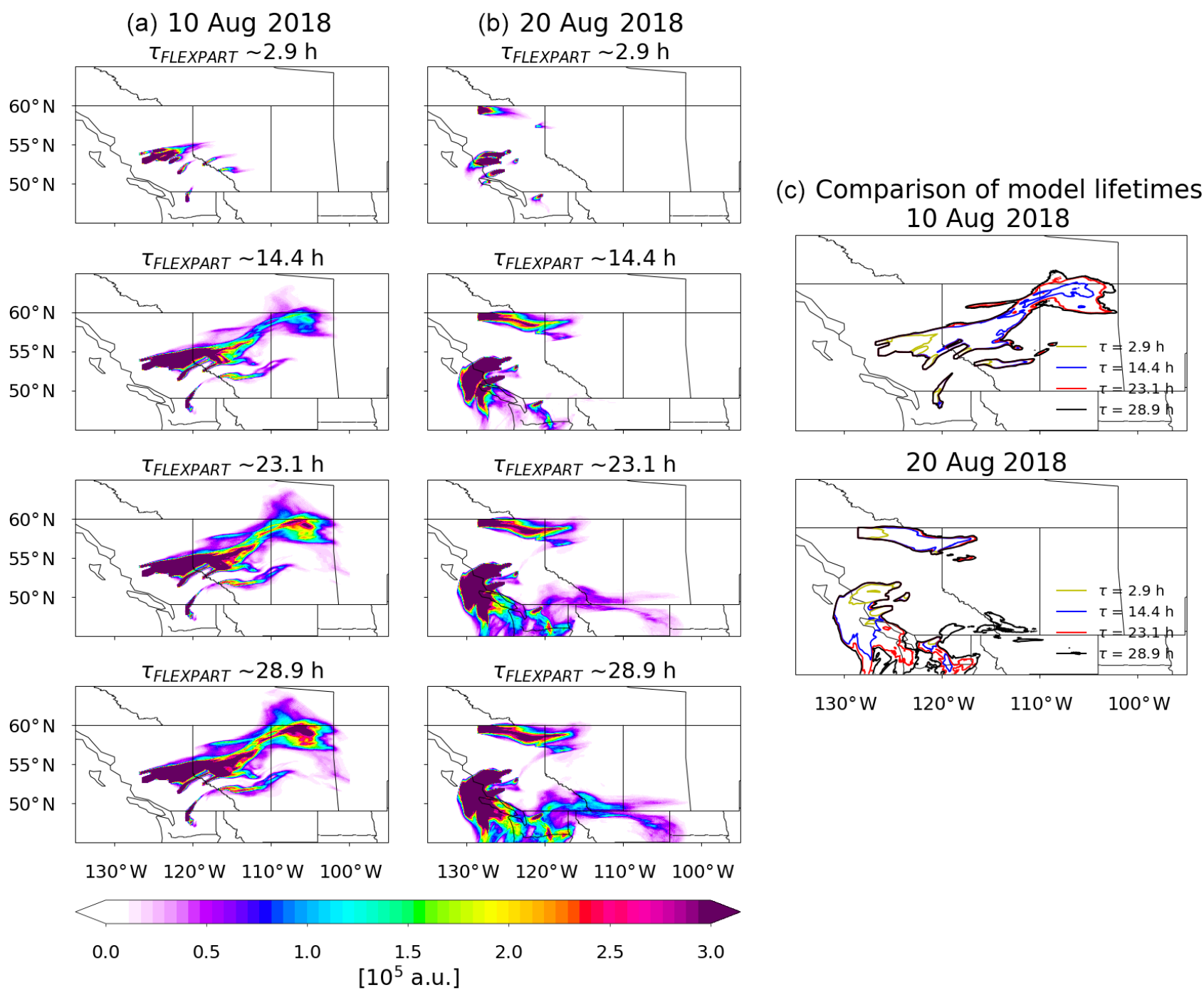

Figure 5. Daily maps of air masses simulated with FLEXPART for 10 and 20 August 2018 are shown (a, b) for selected effective lifetimes $(\sim 2.9,14.4,23.1$, and 28.9 h). (c) Contour plots of simulations for the same lifetimes are compared for 10 and 20 August 2018.

From this figure, it is clear that only for the simulations having effective lifetimes of $23.1 \mathrm{~h}$ or more, a significant fraction of the tracer emitted is present at the end of the plume as observed in the measurements. This is also illustrated in Fig. 6, depicting $\mathrm{CHOCHO}$ and $\mathrm{HCHO}$ maps for 10 August 2018. On top of these maps, contour lines are shown for the simulated air masses assuming effective lifetimes of $\sim 2.9,14.4$, and $28.9 \mathrm{~h}$. It is evident that in both cases the tracer distributions simulated with longer effective lifetimes better describe the observed distribution of $\mathrm{CHOCHO}$ and $\mathrm{HCHO}$.

Figure $7 \mathrm{a}, \mathrm{b}$, and $\mathrm{c}$ present a second comparison of daily maps of CHOCHO and HCHO VCDs with a FLEXPART tracer having an effective lifetime of $28.9 \mathrm{~h}$ for 20 and $21 \mathrm{Au}$ gust 2018. It is evident that, again, the tracer follows the distribution of $\mathrm{CHOCHO}$ and $\mathrm{HCHO}$ observations, similar to the first period studied (see Fig. 4). However, on 20 and 21 August 2018, the CHOCHO and HCHO plumes spread over the ocean, where no sources are expected, and up to the point at which the plume disperses after being transported over a distance of about $\sim 600 \mathrm{~km}$ from the fires.

The observed behaviour of the $\mathrm{CHOCHO}$ and $\mathrm{HCHO}$ plumes is in contrast to the short atmospheric lifetimes resulting from their rapid removal by photolysis and reaction with $\mathrm{OH}$. In addition, $\mathrm{CHOCHO}$ oligomerizes and thus is a source of SOA formation (Schweitzer et al., 1998; Jang et al., 2002; Liggio et al., 2005; Kroll et al., 2005; Loeffler et al., 2006; Volkamer et al., 2007; Fu et al., 2007; Myriokefalitakis et al., 2008; Stavrakou et al., 2009a, c). The simplest explanation of the observations of $\mathrm{CHOCHO}$ and $\mathrm{HCHO}$ is that, during the fire events, both species are transported and/or produced during transport over long distances, resulting in an effective lifetime of about $28.9 \mathrm{~h}$. This would imply the transport of VOC precursors of $\mathrm{CHOCHO}$ and $\mathrm{HCHO}$. 

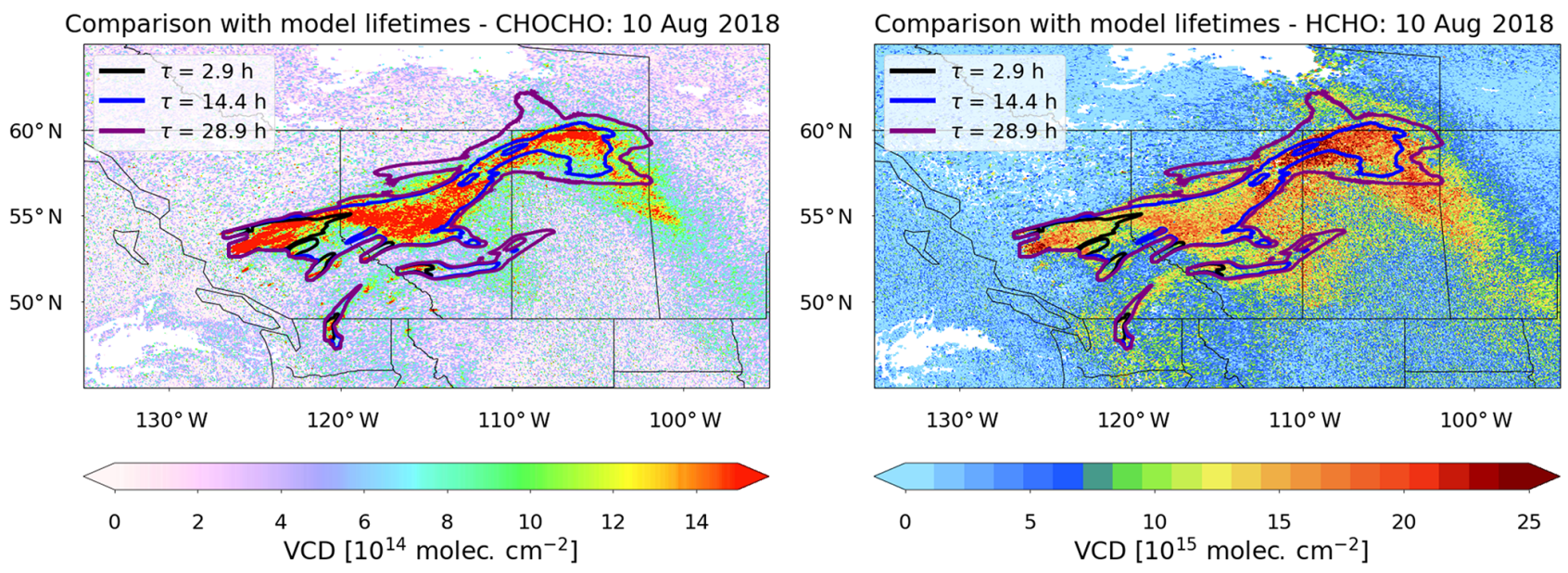

Figure 6. Daily maps of CHOCHO and HCHO VCD retrieved from S5P for 10 August 2018 compared with FLEXPART tracer simulations having three different lifetimes $(\sim 2.9,14.4$, and $28.9 \mathrm{~h})$.

One reason for the longer-range transport of the $\mathrm{CHOCHO}$ and $\mathrm{HCHO}$ plumes is the injection of the biomass burning emissions into the free troposphere, where high wind speeds favour transport over long distances. This is a well-known effect that has also been observed for $\mathrm{NO}_{2}$ in GOME-2 data (Zien et al., 2014). However, even at high wind speeds, the short lifetime of these species would result in much smaller, dispersed plumes than the ones observed. There are three possible explanations for this apparent contradiction:

- Reason 1 is that the lifetimes of CHOCHO and HCHO could be significantly longer than expected in these biomass burning plumes if the $\mathrm{OH}$ mixing ratio and $\mathrm{UV}$ and visible radiation within the plume is much lower than outside the plume. There is, however, no indication that this should be the case; on the contrary, $\mathrm{OH}$ levels in the biomass burning plume are expected to be enhanced (Folkins et al., 1997), leading to a reduction of the expected $\mathrm{CHOCHO}$ and $\mathrm{HCHO}$ lifetimes. In this context, it is interesting to investigate the $\mathrm{NO}_{2} \mathrm{VCD}$ observed. The $\mathrm{NO}_{2}$ plumes coming from the biomass burning are shown in Fig. 8d. During daytime, $\mathrm{NO}_{2}$ is removed in the gas phase by reaction with $\mathrm{OH}$. Provided sufficient $\mathrm{O}_{3}$ is present, the photolysis of $\mathrm{NO}_{2}$ produces $\mathrm{NO}$ and $\mathrm{O}$ which react respectively with $\mathrm{O}_{3}$ to make $\mathrm{NO}_{2}$ and oxygen molecules to make $\mathrm{O}_{3}$. This is known as a "null cycle". $\mathrm{NO}_{2}$ appears to decay relatively rapidly in the plumes coming from the fires. Our assumption that oxidation and photolysis of $\mathrm{CHOCHO}$ and $\mathrm{HCHO}$ are relatively rapid is thus not contradicted by the $\mathrm{NO}_{2}$ decay in the fire plumes.

- Reason 2 is that there could be an efficient recycling process between the gas and aerosol phase, resulting in the observed extended effective lifetimes of CHO$\mathrm{CHO}$ and HCHO. However, this reason is considered unlikely, because there is not yet any strong evidence of HCHO being a precursor of SOA formation, and, as the shape of the plumes for both trace gases is similar, a similar mechanism is expected for both. Also, evidence for the release of $\mathrm{CHOCHO}$ following the formation of oligomers in the aerosol phase is limited (Kroll et al., 2005, and references therein).

- Reason 3 is that the plume could contain CHOCHO and $\mathrm{HCHO}$ precursors, i.e. VOCs, which are slowly oxidized, releasing $\mathrm{CHOCHO}$ and $\mathrm{HCHO}$ along the trajectory. If true, this would result in an apparent increase in lifetime. In order to better assess the $\mathrm{CHOCHO}$ and HCHO spatial distribution seen on 10 August 2018, two additional TROPOMI retrievals have been taken into account. These are column-averaged dry air mole fractions of $\mathrm{CO}$, retrieved by the algorithm described in Schneising et al. (2019), and the $\mathrm{NO}_{2}$ VCD retrieved using an algorithm similar to the one described for the GOME-2 instrument (Richter et al., 2011) and using AMF calculated following the same approach as the one described before for $\mathrm{CHOCHO}$ and $\mathrm{HCHO}$ (see Sect. 2.3). The CO plume shows a similar spatial pattern to those of CHOCHO and $\mathrm{HCHO}$ (see Fig. 8e). As CO is a relatively long-lived tracer of fire emissions, having a lifetime with respect to $\mathrm{OH}$ of months, this supports the fire origin of the plume. As noted above, $\mathrm{NO}_{2}$ is removed by $\mathrm{OH}$ faster than $\mathrm{CHOCHO}$ and $\mathrm{HCHO}$. The $\mathrm{NO}_{2}$ VCD enhancements, in contrast to those of CHO$\mathrm{CHO}$ and $\mathrm{HCHO}$, are limited to the proximity of the fire hot spots (see Fig. 8d). This behaviour agrees with that assumed for a molecule with a short atmospheric lifetime. A true-colour image from the Visible Infrared Imaging Radiometer Suite (VIIRS) clearly shows the distribution of smoke and aerosols produced because of the emission from the fires being transported and transformed (Fig. 8f). The distribution of the aerosol 
(a) CHOCHO VCD: 20 Aug 2018

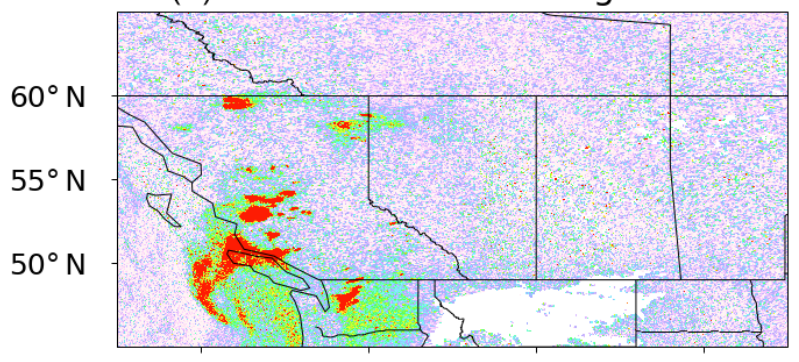

(b) HCHO VCD: 20 Aug 2018

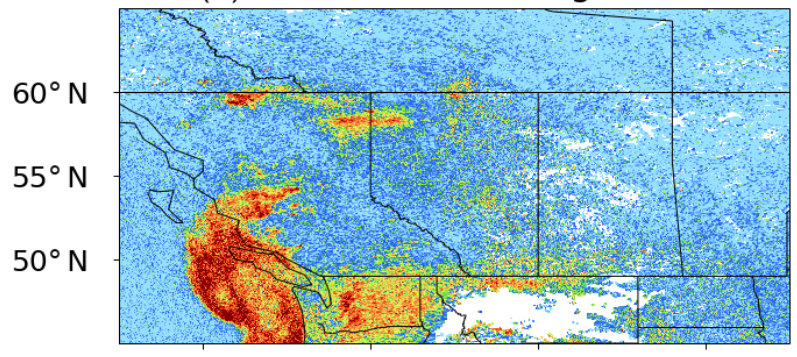

(c) FLEXPART: 20 Aug 2018

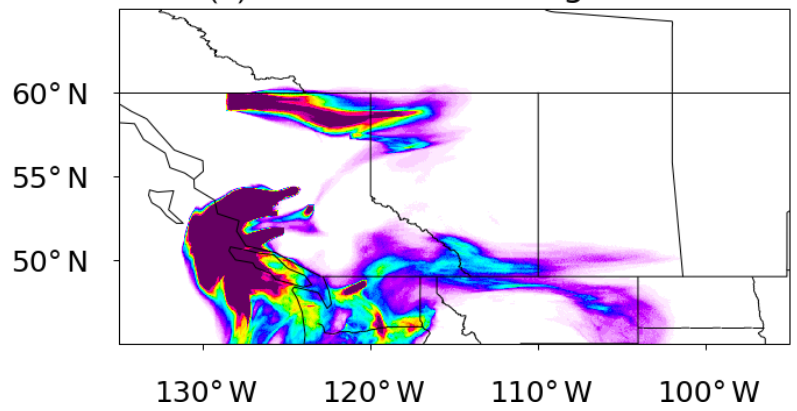

CHOCHO VCD: 21 Aug 2018

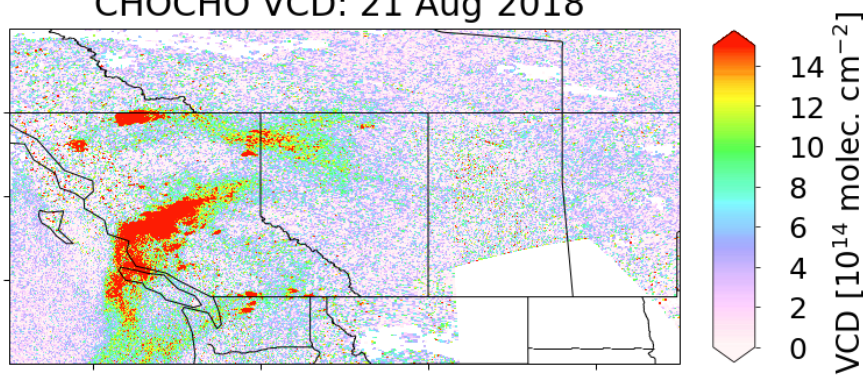

HCHO VCD: 21 Aug 2018
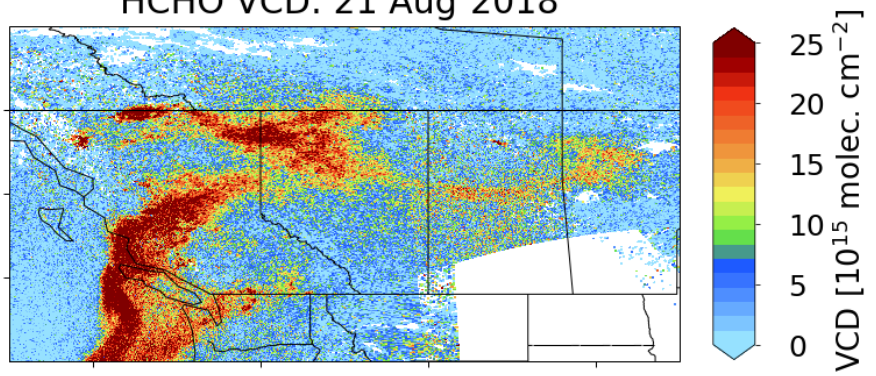

FLEXPART: 21 Aug 2018

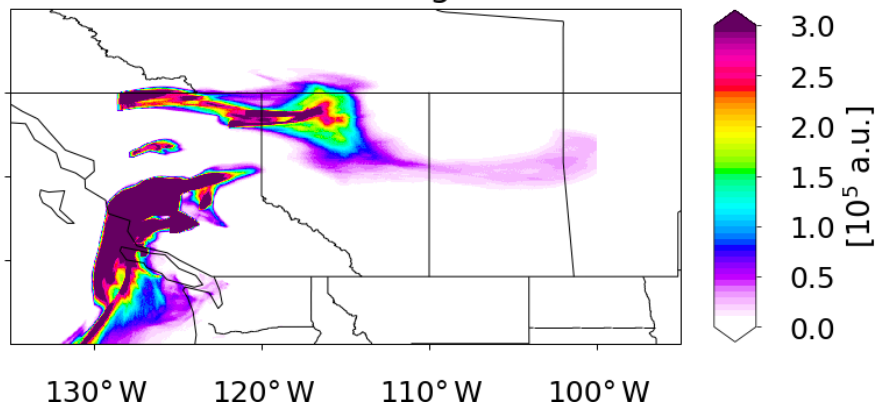

Figure 7. (a, b) Daily CHOCHO and HCHO VCDs retrieved from S5P measurements for the period from 20 to 21 August 2018. (c) Tracer distribution simulated with FLEXPART for the same period assuming a lifetime of $28.9 \mathrm{~h}$. Enhanced CHOCHO columns spread over the ocean in a pattern similar to that simulated by the model tracer.

appears qualitatively to be similar to the $\mathrm{CHOCHO}$, $\mathrm{HCHO}$, and $\mathrm{CO}$ distributions. We infer that the transported plumes are mixtures of $\mathrm{CO}, \mathrm{CHOCHO}, \mathrm{HCHO}$, aerosol, and presumably other pollutants released by the fire. It is interesting to note that $\mathrm{CHOCHO}$ and $\mathrm{CO}$ follow mainly the main plume, while the HCHO distribution is more diffuse and shows enhanced values also over regions where a thinner aerosol plume is visible in the VIIRS image. This distribution may possibly originate from other unidentified fires or another unknown source, which is not included in our FLEXPART simulations.

As additional information, the ratio of $\mathrm{CHOCHO}$ to $\mathrm{HCHO}$, $R_{\mathrm{GF}}$, is presented in Fig. 8c. Larger values of $R_{\mathrm{GF}}$ are found close to the location of the wildfires as already reported in previous publications (Vrekoussis et al., 2010). This is an indication of enhanced primary emissions of $\mathrm{CHOCHO}$ relative to those of $\mathrm{HCHO}$ from fires. Lower $R_{\mathrm{GF}}$ values are found closer to the end of the plume, implying a decreasing production of $\mathrm{CHOCHO}$ relative to that of $\mathrm{HCHO}$ during the transport of polluted air in the plume. Another potential explanation would be the mixing of air from different origins, having lower $\mathrm{CHOCHO}$ and/or higher $\mathrm{HCHO}$ concentrations, during the plume transport. This is, however, not confirmed by the observed $\mathrm{CO}$ behaviour, which shows a similar spatial distribution to $\mathrm{CHOCHO}$ and $\mathrm{HCHO}$.

The comparison of retrieved S5P columns and FLEXPART tracer simulations discussed is based on a number of simplifications. The observational conditions of the biomass burning plumes are complex, and aerosol scattering and absorption impact on the sensitivity of the retrievals. While this is taken into account by using air mass factors for elevated plumes positioned at altitudes derived from CALIPSO ob- 
(a) CHOCHO VCD: 10 Aug 2018

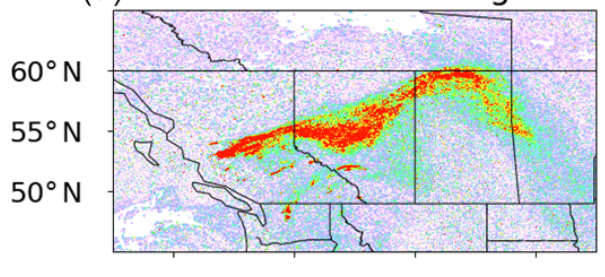

$130^{\circ} \mathrm{W} \quad 120^{\circ} \mathrm{W} \quad 110^{\circ} \mathrm{W} \quad 100^{\circ} \mathrm{W}$

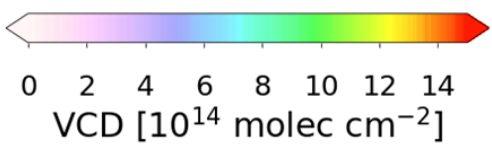

(d) $\mathrm{NO}_{2}$ VCD: 10 Aug 2018

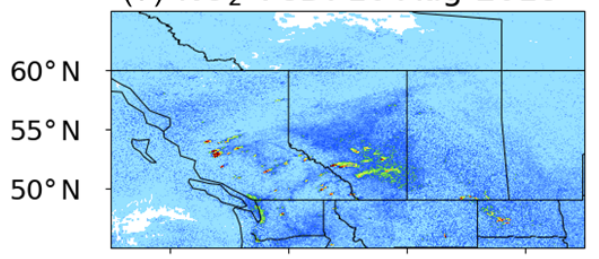

$130^{\circ} \mathrm{W} \quad 120^{\circ} \mathrm{W} \quad 110^{\circ} \mathrm{W} \quad 100^{\circ} \mathrm{W}$

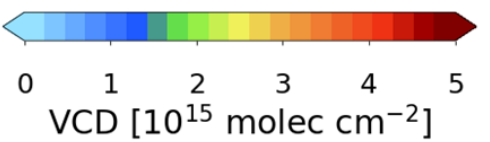

(b) HCHO VCD: 10 Aug 2018

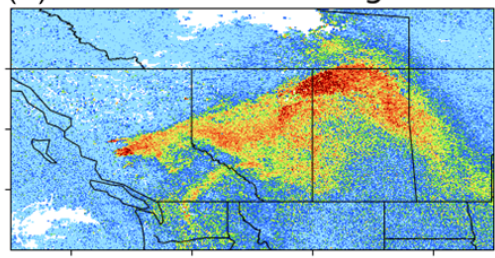

$130^{\circ} \mathrm{W} \quad 120^{\circ} \mathrm{W} \quad 110^{\circ} \mathrm{W} \quad 100^{\circ} \mathrm{W}$

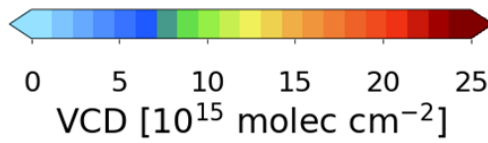

(e) CO: 10 Aug 2018

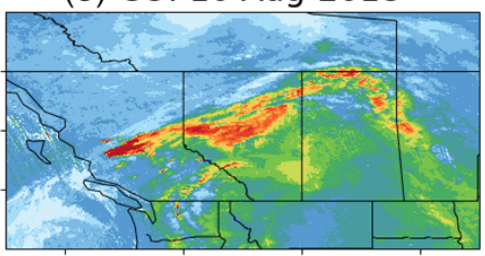

$130^{\circ} \mathrm{W} \quad 120^{\circ} \mathrm{W} \quad 110^{\circ} \mathrm{W} \quad 100^{\circ} \mathrm{W}$

(f)

f) VIIRS-SNPP RGB: 10 Aug 2018

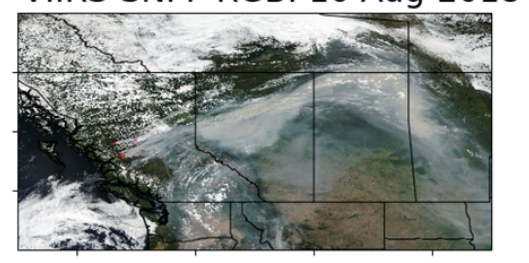

$130^{\circ} \mathrm{W} \quad 120^{\circ} \mathrm{W} \quad 110^{\circ} \mathrm{W} 100^{\circ} \mathrm{W}$

(c) Ratio GF 10 Aug 2018

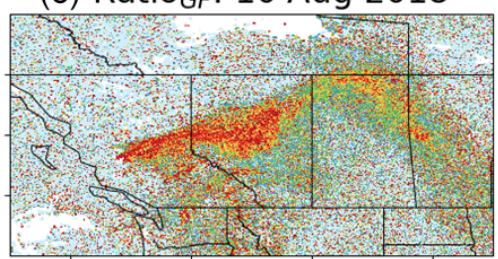

$130^{\circ} \mathrm{W} \quad 120^{\circ} \mathrm{W} \quad 110^{\circ} \mathrm{W} \quad 100^{\circ} \mathrm{W}$

$\mathrm{R}_{G F}\left[10^{-2}\right]$

$\begin{array}{lllllll}0 & 50 & 100 & 150 & 200 & 250 & 300\end{array}$

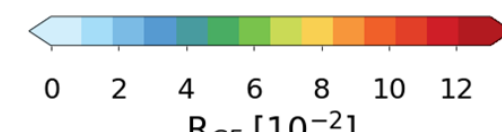

Figure 8. Panels (a), (b), (d), and (e) show the CHOCHO, $\mathrm{HCHO}, \mathrm{NO}_{2}$, and $\mathrm{CO}$ columns, respectively, retrieved from S5P measurements for 10 August 2018. Note that CO columns are unfiltered and only represent a qualitative description of the plume. The AMFs used for $\mathrm{CHOCHO}, \mathrm{HCHO}$, and $\mathrm{NO}_{2}$ are appropriate for the biomass burning plume only. Panel (c) depicts the calculated $\mathrm{CHOCHO}-\mathrm{Ho}-\mathrm{HCHO}$ ratio $\left(R_{\mathrm{GF}}\right)$ for the same day. Panel (f) shows a true-colour image of the aerosol distribution from VIIRS for 10 August 2018.

servations, there remains considerable uncertainty with respect to absolute values. Aerosol loading and optical properties will vary along the plume and thus will the retrieval sensitivities. This is not modelled explicitly in this study. However, the differences apparent between the spatial distributions of $\mathrm{CHOCHO}$ and $\mathrm{NO}_{2}$, which are retrieved in similar spectral regions, provide evidence for the fact that measurement sensitivity does not explain the differences in the observed VCD plume patterns. Another crucial simplification is the assumption of constant fire emissions and the proportionality of FRP and emission strength in the FLEXPART simulations. In reality, fire emissions will also depend on the type of biomass burned, the age of the fire, the time of the day, and the environmental conditions, and this will have an effect on the trace-gas distribution along the plume, which reflects both chemical transformation and the history of emissions. Modelling of this time evolution is complex, if possible at all, and out of the scope of this study. However, the observation that both $\mathrm{CHOCHO}$ and $\mathrm{HCHO}$ are present in the biomass burning plume after extended time periods and over long distances is robust and is best explained by the release of $\mathrm{CHOCHO}$ and $\mathrm{HCHO}$ from the transformation of longer-lived precursors and/or efficient recycling processes in the plume as discussed above.

\section{Summary and conclusions}

The retrieval of $\mathrm{CHOCHO}$ and $\mathrm{HCHO}$ VCDs from measurements of TROPOMI on board the Sentinel-5 Precursor satellite is reported. This will extend the datasets already available from the SCIAMACHY, GOME-2, and OMI instruments. The advantage of the high spatial resolution and low noise of TROPOMI for studying specific geophysical phenomena is well demonstrated in the features and plumes seen in the $\mathrm{CHOCHO}, \mathrm{HCHO}, \mathrm{CO}$, and $\mathrm{NO}_{2}$ VCDs.

In this case study, the satellite data show clear evidence for pyrogenic emissions of $\mathrm{CHOCHO}$ and $\mathrm{HCHO}$ during the wildfire season in summer 2018 in British Columbia, Canada. The spatial and temporal pattern of the highest retrieved $\mathrm{CHOCHO}$ and $\mathrm{HCHO}$ VCDs are associated with areas having high fire radiative power, as identified in the MODIS fire data products. This indicates that, in these areas, pyrogenic emissions are the dominant source of $\mathrm{CHOCHO}$ and $\mathrm{HCHO}$. In addition to local enhancements of $\mathrm{NO}_{2}, \mathrm{CHO}-$ $\mathrm{CHO}$, and $\mathrm{HCHO}$, close to the fires, extended plumes of el- 
evated $\mathrm{CHOCHO}$ and $\mathrm{HCHO} \mathrm{VCD}$ are observed downwind from the fires. This is in contrast to the behaviour of $\mathrm{NO}_{2}$, which is also transported but is short lived. The spatial and temporal $\mathrm{CHOCHO}$ and $\mathrm{HCHO}$ distribution observed from satellite follows a similar pattern to that of $\mathrm{CO}$, which is long lived, and that simulated by FLEXPART, initialized by tracer emissions starting at known fire locations. Enhanced CHO$\mathrm{CHO}$ and $\mathrm{HCHO}$ concentrations were found in the S5P data up to $1500 \mathrm{~km}$ from their sources.

In order to obtain reasonable agreement between the model results and the measurements, an effective tracer lifetime of more than $20 \mathrm{~h}$ and up to $28.9 \mathrm{~h}$ needs to be assumed in the FLEXPART simulations. This is significantly longer than the anticipated lifetimes of $\mathrm{CHOCHO}$ and HCHO. The transport of $\mathrm{CHOCHO}$ and $\mathrm{HCHO}$ along the length of the plume could be associated with these trace gases being lifted from the boundary layer into the free troposphere, where high wind speeds lead to rapid transport. The long apparent lifetime of $\mathrm{CHOCHO}$ and $\mathrm{HCHO}$ in the transported plumes could be explained by a real increase in their lifetime in the plume because of photochemical conditions in the plume, which we consider unexpected. Based on our current knowledge, the most probable explanation of the apparent long lifetime of $\mathrm{CHOCHO}$ and $\mathrm{HCHO}$ would be formation within the plume caused by the oxidation of a mixture of longerlived emitted VOC precursors (e.g. methanol, ethanol, acetylene, aromatics, glycolaldehyde, ethylene, etc.), that form $\mathrm{CHOCHO}$ and $\mathrm{HCHO}$ at different rates. Further research is needed to investigate how frequent such fire-related longrange transport events of VOCs are. The chemical mechanism of the formation of $\mathrm{CHOCHO}$ and $\mathrm{HCHO}$ in the plumes downwind of the fires needs to be identified. The assessment of the number of such fires events and their relevance for tropospheric $\mathrm{O}_{3}$ and aerosol production downwind of the fires, as well as air quality, is required.

Data availability. The Global Fire Assimilation System data are available in the database of the Copernicus Atmosphere Monitoring Service (https://apps.ecmwf.int/datasets/data/cams-gfas/, last access: 7 November 2018). The CALIPSO Cloud and Aerosol Lidar Level 2 Aerosol Profile Version 3-40 Product (CAL_LID_L2_05kmAPro-Prov-V3-40) data are available at the NASA Langley Research Center Atmospheric Science Data Center (https://search.earthdata.nasa.gov/search/granules?p= C1356785530-LARC_ASDC\&tl=1566319789!4!!, last access: 29 March 2019). The Suomi NPP Visible Infrared Imaging Radiometer Suite (VIIRS) true-colour images are available at the NASA Langley Research Center Atmospheric Science Data Center (https://go.nasa.gov/38SJDxH, last access: 19 June 2019). The FLEXPART simulations, level 2 and level 3, of $\mathrm{CHOCHO}$ and $\mathrm{HCHO}$ are available at the Institute of Environmental Physics of the University of Bremen (http: //www.iup.uni-bremen.de/doas/data/glyoxal/S5P/alvarado_2020/, last access: 28 January 2020). The underlying data of the figures are available upon request (contact person is Leonardo M. A. Alvarado, lalvarado@iup.physik.uni-bremen.de).

Author contributions. LMAA, AR, and JPB prepared the article with the contribution of all authors, and they developed the glyoxal, formaldehyde, and $\mathrm{NO}_{2}$ retrievals for TROPOMI measurements. $\mathrm{MV}, \mathrm{AH}$, and ABKH designed and performed the FLEXPART simulations of the air masses assuming different effective lifetimes. OS developed the $\mathrm{CO}$ retrieval and provided the $\mathrm{CO}$ data for the comparison with glyoxal and formaldehyde products.

Competing interests. The authors declare that they have no conflict of interest.

Special issue statement. This article is part of the special issue "TROPOMI on Sentinel-5 Precursor: first year in operation (AMT/ACPT inter-journal SI)". It is not associated with a conference.

Acknowledgements. This study was funded by the University of Bremen. Copernicus Sentinel-5P lv1 data from 2018 were used in this study. This publication contains modified COPERNICUS Sentinel data (2018). We thank the Copernicus Atmosphere Monitoring Service (CAMS) GFAS team for providing the GFASv1.0 FRP and injection height products. FLEXPART simulations were conducted on the University of Bremen's high-performance computing cluster Aether, funded by DFG within the scope of the Excellence Initiative. VIIRS and CALIPSO data were obtained from the NASA Langley Research Center Atmospheric Science Data Center. FLEXPART simulation results were generated using Copernicus Climate Change Service Information (ERA5).

This is, in part, preparatory work for the analysis of the data from the DFG SPP HALO EMeRGe project, which has one focus on biomass burning and the long-range transport of such plumes. We thank Abram Sanders (European Organisation for the Exploitation of Meteorological Satellites, Darmstadt) for providing support in the preparation of CALIPSO data for the computation of $\mathrm{CHOCHO}$ and HCHO AMFs.

Financial support. The article processing charges for this openaccess publication were covered by the University of Bremen.

Review statement. This paper was edited by Robert McLaren and reviewed by two anonymous referees.

\section{References}

Abbot, D. S., Palmer, P. I., Martin, R. V., Chance, K. V., Jacob, D. J., and Guenther, A.: Seasonal and interannual variability of North American isoprene emissions as determined by formalde- 
hyde column measurements from space, Geophys. Res. Lett., 30, 1886, https://doi.org/10.1029/2003GL017336, 2003.

Alvarado, L. M. A.: Investigating the role of glyoxal using satellite and MAX-DOAS measurements, $\mathrm{PhD}$, University of Bremen, Bremen, available at: http://nbn-resolving.de/urn:nbn:de: gbv:46-00105347-16 (last access: 28 August 2019), 2016.

Alvarado, L. M. A., Richter, A., Vrekoussis, M., Wittrock, F., Hilboll, A., Schreier, S. F., and Burrows, J. P.: An improved glyoxal retrieval from OMI measurements, Atmos. Meas. Tech., 7, 4133-4150, https://doi.org/10.5194/amt-7-4133-2014, 2014.

Alvarado, L. M. A., Richter, A., Vrekoussis, M., Wittrock, F., Hilboll, A., Schreier, S. F., and Burrows, J. P.: Investigating the Link Between Glyoxal and Biogenic Activities, in: Towards an Interdisciplinary Approach in Earth System Science, edited by: Lohmann, G., Meggers, H., Unnithan, V., Wolf-Gladrow, D., Notholt, J., and Bracher, A., pp. 59-65, Springer International Publishing, Cham, Germany, https://doi.org/10.1007/978-3-31913865-7_7, 2015.

Atkinson, R.: Atmospheric chemistry of VOCs and $\mathrm{NO}_{x}$, Atmos. Environ., 34, 2063-2101, https://doi.org/10.1016/S13522310(99)00460-4, 2000.

Behrens, L. K., Hilboll, A., Richter, A., Peters, E., Alvarado, L. M. A., Kalisz Hedegaard, A. B., Wittrock, F., Burrows, J. P., and Vrekoussis, M.: Detection of outflow of formaldehyde and glyoxal from the African continent to the Atlantic Ocean with a MAX-DOAS instrument, Atmos. Chem. Phys., 19, 1025710278, https://doi.org/10.5194/acp-19-10257-2019, 2019.

Bovensmann, H., Burrows, J. P., Buchwitz, M., Frerick, J., Noël, S., Rozanov, V. V., Chance, K. V., and Goede, A. P. H.: SCIAMACHY: Mission Objectives and Measurement Modes, J. Atmos. Sci., 56, 127-150, https://doi.org/10.1175/15200469(1999)056<0127:SMOAMM>2.0.CO;2, 1999.

Burrows, J. P., Hölzle, E., Goede, A. P. H., Visser, H., and Fricke, W.: SCIAMACHY - scanning imaging absorption spectrometer for atmospheric chartography, Acta Astronaut., 35, 445-451, https://doi.org/10.1016/0094-5765(94)00278-T, 1995.

Burrows, J. P., Weber, M., Buchwitz, M., Rozanov, V., Ladstätter-Weißenmayer, A., Richter, A., DeBeek, R., Hoogen, R., Bramstedt, K., Eichmann, K.-U., Eisinger, M., and Perner, D.: The Global Ozone Monitoring Experiment (GOME): Mission Concept and First Scientific Results, J. Atmos. Sci., 56, 151-175, https://doi.org/10.1175/15200469(1999)056<0151:TGOMEG>2.0.CO;2, 1999.

Chan Miller, C., Gonzalez Abad, G., Wang, H., Liu, X., Kurosu, T., Jacob, D. J., and Chance, K.: Glyoxal retrieval from the Ozone Monitoring Instrument, Atmos. Meas. Tech., 7, 38913907, https://doi.org/10.5194/amt-7-3891-2014, 2014.

De Smedt, I., Müller, J.-F., Stavrakou, T., van der A, R., Eskes, H., and Van Roozendael, M.: Twelve years of global observations of formaldehyde in the troposphere using GOME and SCIAMACHY sensors, Atmos. Chem. Phys., 8, 4947-4963, https://doi.org/10.5194/acp-8-4947-2008, 2008.

De Smedt, I., Van Roozendael, M., Stavrakou, T., Müller, J.-F., Lerot, C., Theys, N., Valks, P., Hao, N., and van der A, R.: Improved retrieval of global tropospheric formaldehyde columns from GOME-2/MetOp-A addressing noise reduction and instrumental degradation issues, Atmos. Meas. Tech., 5, 2933-2949, https://doi.org/10.5194/amt-5-2933-2012, 2012.
De Smedt, I., Stavrakou, T., Hendrick, F., Danckaert, T., Vlemmix, T., Pinardi, G., Theys, N., Lerot, C., Gielen, C., Vigouroux, C., Hermans, C., Fayt, C., Veefkind, P., Müller, J.-F., and Van Roozendael, M.: Diurnal, seasonal and long-term variations of global formaldehyde columns inferred from combined OMI and GOME-2 observations, Atmos. Chem. Phys., 15, 12519-12545, https://doi.org/10.5194/acp-15-12519-2015, 2015.

De Smedt, I., Theys, N., Yu, H., Danckaert, T., Lerot, C., Compernolle, S., Van Roozendael, M., Richter, A., Hilboll, A., Peters, E., Pedergnana, M., Loyola, D., Beirle, S., Wagner, T., Eskes, H., van Geffen, J., Boersma, K. F., and Veefkind, P.: Algorithm theoretical baseline for formaldehyde retrievals from S5P TROPOMI and from the QA4ECV project, Atmos. Meas. Tech., 11, 23952426, https://doi.org/10.5194/amt-11-2395-2018, 2018.

Fleischmann, O. C., Hartmann, M., Burrows, J. P., and Orphal, J.: New ultraviolet absorption cross-sections of $\mathrm{BrO}$ at atmospheric temperatures measured by time-windowing Fourier transform spectroscopy, J. Photochem. Photobiol. A, 168, 117132, https://doi.org/10.1016/j.jphotochem.2004.03.026, 2004.

Folkins, I., Wennberg, P. O., Hanisco, T. F., Anderson, J. G., and Salawitch, R. J.: $\mathrm{OH}, \mathrm{HO}_{2}$, and $\mathrm{NO}$ in two biomass burning plumes: Sources of $\mathrm{HO}_{x}$ and implications for ozone production, Geophys. Res. Lett., 24, 3185-3188, https://doi.org/10.1029/97GL03047, 1997.

Fu, T.-M., Jacob, D. J., Palmer, P. I., Chance, K., Wang, Y. X., Barletta, B., Blake, D. R., Stanton, J. C., and Pilling, M. J.: Spacebased formaldehyde measurements as constraints on volatile organic compound emissions in east and south Asia and implications for ozone, J. Geophys. Res.-Atmos., 112, D06312, https://doi.org/10.1029/2006JD007853, 2007.

González Abad, G., Liu, X., Chance, K., Wang, H., Kurosu, T. P., and Suleiman, R.: Updated Smithsonian Astrophysical Observatory Ozone Monitoring Instrument (SAO OMI) formaldehyde retrieval, Atmos. Meas. Tech., 8, 19-32, https://doi.org/10.5194/amt-8-19-2015, 2015.

Guenther, A., Geron, C., Pierce, T., Lamb, B., Harley, P., and Fall, R.: Natural emissions of non-methane volatile organic compounds, carbon monoxide, and oxides of nitrogen from North America, Atmos. Environ., 34, 2205-2230, https://doi.org/10.1016/S1352-2310(99)00465-3, 2000.

Guenther, A., Karl, T., Harley, P., Wiedinmyer, C., Palmer, P. I., and Geron, C.: Estimates of global terrestrial isoprene emissions using MEGAN (Model of Emissions of Gases and Aerosols from Nature), Atmos. Chem. Phys., 6, 3181-3210, https://doi.org/10.5194/acp-6-3181-2006, 2006.

Hewson, W., Bösch, H., Barkley, M. P., and De Smedt, I.: Characterisation of GOME-2 formaldehyde retrieval sensitivity, Atmos. Meas. Tech., 6, 371-386, https://doi.org/10.5194/amt-6371-2013, 2013.

Jang, M., Czoschke, N. M., Lee, S., and Kamens, R. M.: Heterogeneous Atmospheric Aerosol Production by AcidCatalyzed Particle-Phase Reactions, Science, 298, 814-817, https://doi.org/10.1126/science.1075798, 2002.

Justice, C. O., Giglio, L., Korontzi, S., Owens, J., Morisette, J. T., Roy, D., Descloitres, J., Alleaume, S., Petitcolin, F., and Kaufman, Y.: The MODIS fire products, Remote Sens. Environ., 83, 244-262, https://doi.org/10.1016/S0034-4257(02)00076-7, 2002. 
Kaiser, J. W., Heil, A., Andreae, M. O., Benedetti, A., Chubarova, N., Jones, L., Morcrette, J.-J., Razinger, M., Schultz, M. G., Suttie, M., and van der Werf, G. R.: Biomass burning emissions estimated with a global fire assimilation system based on observed fire radiative power, Biogeosciences, 9, 527-554, https://doi.org/10.5194/bg-9-527-2012, 2012.

Kansal, A.: Sources and reactivity of NMHCs and VOCs in the atmosphere: A review, J. Hazard. Mater., 166, 17-26, https://doi.org/10.1016/j.jhazmat.2008.11.048, 2009.

Kroll, J. H., Ng, N. L., Murphy, S. M., Varutbangkul, V., Flagan, R. C., and Seinfeld, J. H.: Chamber studies of secondary organic aerosol growth by reactive uptake of simple carbonyl compounds, J. Geophys. Res., 110, D23207, https://doi.org/10.1029/2005JD006004, 2005.

Kurosu, T. P., Chance, K., and Volkamer, R.: Measurements of $\mathrm{HCHO}, \mathrm{CHOCHO}$, and $\mathrm{BrO}$ from the Ozone Monitoring Instrument on EOS AURA, in: Proceedings of Envisat Symposium, ESA earthnet online, Montreux (Switzerland), available at: https://earth.esa.int/envisatsymposium/proceedings/sessions/ 3G1/507603ch.pdf (last access: 28 August 2019), 2007.

Lerot, C., Stavrakou, T., De Smedt, I., Müller, J.-F., and Van Roozendael, M.: Glyoxal vertical columns from GOME2 backscattered light measurements and comparisons with a global model, Atmos. Chem. Phys., 10, 12059-12072, https://doi.org/10.5194/acp-10-12059-2010, 2010.

Levelt, P. F., van den Oord, G. H. J., Dobber, M. R., Malkki, A., Visser, H., Vries, J. de, Stammes, P., Lundell, J. O. V., and Saari, H.: The ozone monitoring instrument, IEEE T. Geosci. Remote, 44, 1093-1101, https://doi.org/10.1109/TGRS.2006.872333, 2006.

Liggio, J., Li, S.-M., and McLaren, R.: Reactive uptake of glyoxal by particulate matter, J. Geophys. Res.-Atmos., 110, D10304, https://doi.org/10.1029/2004JD005113, 2005.

Liu, Z., Wang, Y., Vrekoussis, M., Richter, A., Wittrock, F., Burrows, J. P., Shao, M., Chang, C.-C., Liu, S.-C., Wang, H., and Chen, C.: Exploring the missing source of glyoxal (CHOCHO) over China, Geophys. Res. Lett., 39, L10812, https://doi.org/10.1029/2012GL051645, 2012.

Loeffler, K. W., Koehler, C. A., Paul, N. M., and De Haan, D. O.: Oligomer Formation in Evaporating Aqueous Glyoxal and Methyl Glyoxal Solutions, Environ. Sci. Technol., 40, 63186323, https://doi.org/10.1021/es060810w, 2006.

Marais, E. A., Jacob, D. J., Kurosu, T. P., Chance, K., Murphy, J. G., Reeves, C., Mills, G., Casadio, S., Millet, D. B., Barkley, M. P., Paulot, F., and Mao, J.: Isoprene emissions in Africa inferred from OMI observations of formaldehyde columns, Atmos. Chem. Phys., 12, 6219-6235, https://doi.org/10.5194/acp12-6219-2012, 2012.

Mason, J. D., Cone, M. T., and Fry, E. S.: Ultraviolet (250-550 nm) absorption spectrum of pure water, Appl. Optics, 55, 7163-7172, https://doi.org/10.1364/AO.55.007163, 2016.

Meller, R. and Moortgat, G. K.: Temperature dependence of the absorption cross sections of formaldehyde between 223 and $323 \mathrm{~K}$ in the wavelength range $225-375 \mathrm{~nm}$, J. Geophys. Res., 105, 7089-7101, https://doi.org/10.1029/1999JD901074, 2000.

Munro, R., Lang, R., Klaes, D., Poli, G., Retscher, C., Lindstrot, R., Huckle, R., Lacan, A., Grzegorski, M., Holdak, A., Kokhanovsky, A., Livschitz, J., and Eisinger, M.: The GOME2 instrument on the Metop series of satellites: instrument design, calibration, and level 1 data processing - an overview, Atmos. Meas. Tech., 9, 1279-1301, https://doi.org/10.5194/amt-9-12792016, 2016.

Myriokefalitakis, S., Vrekoussis, M., Tsigaridis, K., Wittrock, F., Richter, A., Brühl, C., Volkamer, R., Burrows, J. P., and Kanakidou, M.: The influence of natural and anthropogenic secondary sources on the glyoxal global distribution, Atmos. Chem. Phys., 8, 4965-4981, https://doi.org/10.5194/acp-8-4965-2008, 2008.

Natural Resources Canada: Canadian Wildland Fire Information System, Archived reports, available at: http://cwfis.cfs.nrcan.gc.ca/report/archives?year=2018\&month= 08\&day=29\&process=Submit (last access: 12 April 2019), 2018.

Palmer, P. I., Jacob, D. J., Chance, K., Martin, R. V., Spurr, R. J. D., Kurosu, T. P., Bey, I., Yantosca, R., Fiore, A., and Li, Q.: Air mass factor formulation for spectroscopic measurements from satellites: Application to formaldehyde retrievals from the Global Ozone Monitoring Experiment, J. Geophys. Res.-Atmos., 106, 14539-14550, https://doi.org/10.1029/2000JD900772, 2001.

Palmer, P. I., Jacob, D. J., Fiore, A. M., Martin, R. V., Chance, K., and Kurosu, T. P.: Mapping isoprene emissions over North America using formaldehyde column observations from space, J. Geophys. Res.-Atmos., 108, 4180, https://doi.org/10.1029/2002JD002153, 2003.

Pisso, I., Sollum, E., Grythe, H., Kristiansen, N. I., Cassiani, M., Eckhardt, S., Arnold, D., Morton, D., Thompson, R. L., Groot Zwaaftink, C. D., Evangeliou, N., Sodemann, H., Haimberger, L., Henne, S., Brunner, D., Burkhart, J. F., Fouilloux, A., Brioude, J., Philipp, A., Seibert, P., and Stohl, A.: The Lagrangian particle dispersion model FLEXPART version 10.4, Geosci. Model Dev., 12, 4955-4997, https://doi.org/10.5194/gmd-12-4955-2019, 2019.

Pukīie, J., Kühl, S., Deutschmann, T., Platt, U., and Wagner, T.: Extending differential optical absorption spectroscopy for limb measurements in the UV, Atmos. Meas. Tech., 3, 631-653, https://doi.org/10.5194/amt-3-631-2010, 2010.

Rémy, S., Veira, A., Paugam, R., Sofiev, M., Kaiser, J. W., Marenco, F., Burton, S. P., Benedetti, A., Engelen, R. J., Ferrare, R., and Hair, J. W.: Two global data sets of daily fire emission injection heights since 2003, Atmos. Chem. Phys., 17, 2921-2942, https://doi.org/10.5194/acp-17-2921-2017, 2017.

Richter, A., Begoin, M., Hilboll, A., and Burrows, J. P.: An improved $\mathrm{NO}_{2}$ retrieval for the GOME-2 satellite instrument, Atmos. Meas. Tech., 4, 1147-1159, https://doi.org/10.5194/amt-41147-2011, 2011.

Rothman, L. S., Gordon, I. E., Babikov, Y., Barbe, A., Chris Benner, D., Bernath, P. F., Birk, M., Bizzocchi, L., Boudon, V., Brown, L. R., Campargue, A., Chance, K., Cohen, E. A., Coudert, L. H., Devi, V. M., Drouin, B. J., Fayt, A., Flaud, J.-M., Gamache, R. R., Harrison, J. J., Hartmann, J.-M., Hill, C., Hodges, J. T., Jacquemart, D., Jolly, A., Lamouroux, J., Le Roy, R. J., Li, G., Long, D. A., Lyulin, O. M., Mackie, C. J., Massie, S. T., Mikhailenko, S., Müller, H. S. P., Naumenko, O. V., Nikitin, A. V., Orphal, J., Perevalov, V., Perrin, A., Polovtseva, E. R., Richard, C., Smith, M. A. H., Starikova, E., Sung, K., Tashkun, S., Tennyson, J., Toon, G. C., Tyuterev, V. G., and Wagner, G.: The HITRAN2012 molecular spectroscopic database, J. Quant. Spectrosc. Ra., 130, 4-50, https://doi.org/10.1016/j.jqsrt.2013.07.002, 2013. 
Rozanov, V. V., Rozanov, A. V., Kokhanovsky, A. A., and Burrows, J. P.: Radiative transfer through terrestrial atmosphere and ocean: Software package SCIATRAN, J. Quant. Spectrosc. Ra., 133, 13-71, https://doi.org/10.1016/j.jqsrt.2013.07.004, 2013.

Schneising, O., Buchwitz, M., Reuter, M., Bovensmann, H., Burrows, J. P., Borsdorff, T., Deutscher, N. M., Feist, D. G., Griffith, D. W. T., Hase, F., Hermans, C., Iraci, L. T., Kivi, R., Landgraf, J., Morino, I., Notholt, J., Petri, C., Pollard, D. F., Roche, S., Shiomi, K., Strong, K., Sussmann, R., Velazco, V. A., Warneke, T., and Wunch, D.: A scientific algorithm to simultaneously retrieve carbon monoxide and methane from TROPOMI onboard Sentinel-5 Precursor, Atmos. Meas. Tech., 12, 67716802, https://doi.org/10.5194/amt-12-6771-2019, 2019.

Schweitzer, F., Magi, L., Mirabel, P., and George, C.: Uptake Rate Measurements of Methanesulfonic Acid and Glyoxal by Aqueous Droplets, J. Phys. Chem. A, 102, 593-600, https://doi.org/10.1021/jp972451k, 1998.

Serdyuchenko, A., Gorshelev, V., Weber, M., Chehade, W., and Burrows, J. P.: High spectral resolution ozone absorption crosssections - Part 2: Temperature dependence, Atmos. Meas. Tech., 7, 625-636, https://doi.org/10.5194/amt-7-625-2014, 2014.

Sinreich, R., Volkamer, R., Filsinger, F., Frieß, U., Kern, C., Platt, U., Sebastián, O., and Wagner, T.: MAX-DOAS detection of glyoxal during ICARTT 2004, Atmos. Chem. Phys., 7, 1293-1303, https://doi.org/10.5194/acp-7-1293-2007, 2007.

Sinreich, R., Coburn, S., Dix, B., and Volkamer, R.: Ship-based detection of glyoxal over the remote tropical Pacific Ocean, Atmos. Chem. Phys., 10, 11359-11371, https://doi.org/10.5194/acp-1011359-2010, 2010

Stavrakou, T., Müller, J.-F., De Smedt, I., Van Roozendael, M., Kanakidou, M., Vrekoussis, M., Wittrock, F., Richter, A., and Burrows, J. P.: The continental source of glyoxal estimated by the synergistic use of spaceborne measurements and inverse modelling, Atmos. Chem. Phys., 9, 8431-8446, https://doi.org/10.5194/acp-9-8431-2009, 2009a.

Stavrakou, T., Müller, J.-F., De Smedt, I., Van Roozendael, M., van der Werf, G. R., Giglio, L., and Guenther, A.: Evaluating the performance of pyrogenic and biogenic emission inventories against one decade of space-based formaldehyde columns, Atmos. Chem. Phys., 9, 1037-1060, https://doi.org/10.5194/acp-91037-2009, 2009b.

Stavrakou, T., Müller, J.-F., De Smedt, I., Van Roozendael, M., van der Werf, G. R., Giglio, L., and Guenther, A.: Global emissions of non-methane hydrocarbons deduced from SCIAMACHY formaldehyde columns through 2003-2006, Atmos. Chem. Phys., 9, 3663-3679, https://doi.org/10.5194/acp-9-36632009, 2009c.

Stohl, A., Forster, C., Frank, A., Seibert, P., and Wotawa, G.: Technical note: The Lagrangian particle dispersion model FLEXPART version 6.2, Atmos. Chem. Phys., 5, 2461-2474, https://doi.org/10.5194/acp-5-2461-2005, 2005.

Thalman, R. and Volkamer, R.: Temperature dependent absorption cross-sections of $\mathrm{O}_{2}-\mathrm{O}_{2}$ collision pairs between 340 and $630 \mathrm{~nm}$ and at atmospherically relevant pressure, Phys. Chem. Chem. Phys., 15, 15371-15381, https://doi.org/10.1039/c3cp50968k, 2013.

Urbanski, S. P., Reeves, M. C., Corley, R. E., Silverstein, R. P., and Hao, W. M.: Contiguous United States wildland fire emission es- timates during 2003-2015, Earth Syst. Sci. Data, 10, 2241-2274, https://doi.org/10.5194/essd-10-2241-2018, 2018.

Vandaele, A. C., Hermans, C., Simon, P. C., Carleer, M., Colin, R., Fally, S., Mérienne, M. F., Jenouvrier, A., and Coquart, B.: Measurements of the $\mathrm{NO}_{2}$ absorption crosssection from $42000 \mathrm{~cm}^{-1}$ to $10000 \mathrm{~cm}^{-1}(238-1000 \mathrm{~nm})$ at $220 \mathrm{~K}$ and $294 \mathrm{~K}$, J. Quant. Spectrosc. Ra., 59, 171-184, https://doi.org/10.1016/S0022-4073(97)00168-4, 1998.

Vaughan, M. A., Young, S. A., Winker, D. M., Powell, K. A., Omar, A. H., Liu, Z., Hu, Y., and Hostetler, C. A.: Fully automated analysis of space-based lidar data: an overview of the CALIPSO retrieval algorithms and data products, in: Laser Radar Techniques for Atmospheric Sensing, 5575, 16-30, International Society for Optics and Photonics, Laser Radar Techniques for Atmospheric Sensing, https://doi.org/10.1117/12.572024, 2004.

Veefkind, J. P., Aben, I., McMullan, K., Förster, H., de Vries, J., Otter, G., Claas, J., Eskes, H. J., de Haan, J. F., Kleipool, Q., van Weele, M., Hasekamp, O., Hoogeveen, R., Landgraf, J., Snel, R., Tol, P., Ingmann, P., Voors, R., Kruizinga, B., Vink, R., Visser, H., and Levelt, P. F.: TROPOMI on the ESA Sentinel-5 Precursor: A GMES mission for global observations of the atmospheric composition for climate, air quality and ozone layer applications, Remote Sens. Environ., 120, 70-83, https://doi.org/10.1016/j.rse.2011.09.027, 2012.

Volkamer, R., Molina, L. T., Molina, M. J., Shirley, T., and Brune, W. H.: DOAS measurement of glyoxal as an indicator for fast VOC chemistry in urban air, Geophys. Res. Lett., 32, L08806, https://doi.org/10.1029/2005GL022616, 2005a.

Volkamer, R., Spietz, P., Burrows, J., and Platt, U.: Highresolution absorption cross-section of glyoxal in the UV-vis and IR spectral ranges, J. Photochem. Photobiol. A, 172, 35-46, https://doi.org/10.1016/j.jphotochem.2004.11.011, 2005b.

Volkamer, R., San Martini, F., Molina, L. T., Salcedo, D., Jimenez, J. L., and Molina, M. J.: A missing sink for gas-phase glyoxal in Mexico City: Formation of secondary organic aerosol, Geophys. Res. Lett., 34, L19807, https://doi.org/10.1029/2007GL030752, 2007.

Vountas, M., Rozanov, V. V., and Burrows, J. P.: Ring effect: Impact of rotational Raman scattering on radiative transfer in earth's atmosphere, J. Quant. Spectrosc. Ra., 60, 943-961, https://doi.org/10.1016/S0022-4073(97)00186-6, 1998.

Vrekoussis, M., Wittrock, F., Richter, A., and Burrows, J. P.: Temporal and spatial variability of glyoxal as observed from space, Atmos. Chem. Phys., 9, 4485-4504, https://doi.org/10.5194/acp9-4485-2009, 2009.

Vrekoussis, M., Wittrock, F., Richter, A., and Burrows, J. P.: GOME-2 observations of oxygenated VOCs: what can we learn from the ratio glyoxal to formaldehyde on a global scale?, Atmos. Chem. Phys., 10, 10145-10160, https://doi.org/10.5194/acp-10-10145-2010, 2010.

Wittrock, F., Richter, A., Oetjen, H., Burrows, J. P., Kanakidou, M., Myriokefalitakis, S., Volkamer, R., Beirle, S., Platt, U., and Wagner, T.: Simultaneous global observations of glyoxal and formaldehyde from space, Geophys. Res. Lett., 33, L16804, https://doi.org/10.1029/2006GL026310, 2006.

Zhang, Y., Wang, X., Wen, S., Herrmann, H., Yang, W., Huang, X., Zhang, Z., Huang, Z., He, Q., and George, C.: On-road vehicle emissions of glyoxal and methylglyoxal from tunnel 
tests in urban Guangzhou, China, Atmos. Environ., 127, 55-60, https://doi.org/10.1016/j.atmosenv.2015.12.017, 2016.

Zien, A. W., Richter, A., Hilboll, A., Blechschmidt, A.-M., and Burrows, J. P.: Systematic analysis of tropospheric NO2 longrange transport events detected in GOME-2 satellite data, Atmos. Chem. Phys., 14, 7367-7396, https://doi.org/10.5194/acp14-7367-2014, 2014. 